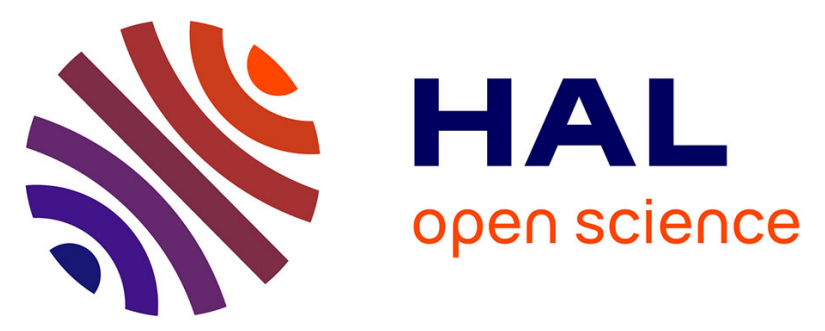

\title{
ReSICLED: a new recovery-conscious design method for complex products based on a multicriteria assessment of the recoverability
}

\author{
Fabrice Mathieux, Daniel Froelich, Pierre Moszkowicz
}

\section{- To cite this version:}

Fabrice Mathieux, Daniel Froelich, Pierre Moszkowicz. ReSICLED: a new recovery-conscious design method for complex products based on a multicriteria assessment of the recoverability. Journal of Cleaner Production, 2008, 2008 (16), pp.277-298. 10.1016/j.clepro.2006.07.026 . hal-01206823v3

\section{HAL Id: hal-01206823 \\ https://hal.science/hal-01206823v3}

Submitted on 29 Sep 2015

HAL is a multi-disciplinary open access archive for the deposit and dissemination of scientific research documents, whether they are published or not. The documents may come from teaching and research institutions in France or abroad, or from public or private research centers.
L'archive ouverte pluridisciplinaire $\mathbf{H A L}$, est destinée au dépôt et à la diffusion de documents scientifiques de niveau recherche, publiés ou non, émanant des établissements d'enseignement et de recherche français ou étrangers, des laboratoires publics ou privés. 


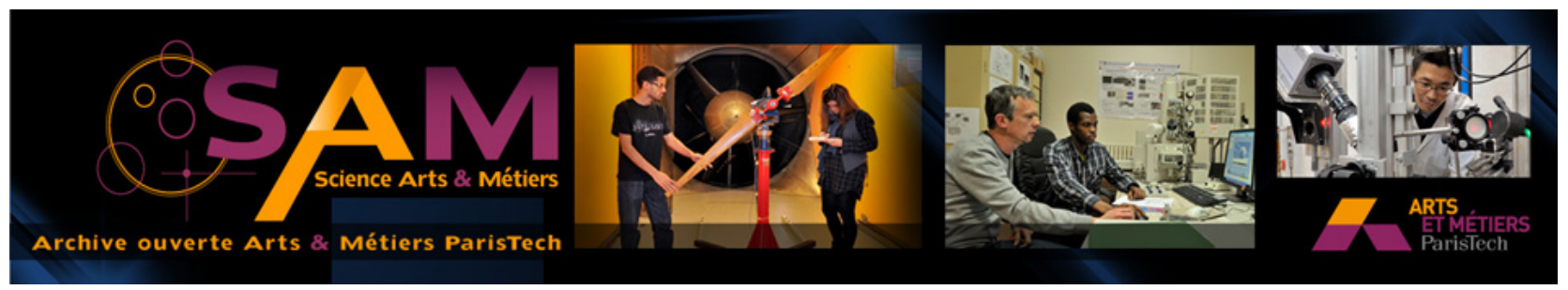

\section{Science Arts \& Métiers (SAM)}

is an open access repository that collects the work of Arts et Métiers ParisTech researchers and makes it freely available over the web where possible.

This is an author-deposited version published in: http://sam.ensam.eu

Handle ID: .http://hdl.handle.net/10985/10247

\section{To cite this version :}

Fabrice MATHIEUX, Daniel FROELICH, Pierre MOSZKOWICZ - ReSICLED: a new recoveryconscious design method for complex products based on a multicriteria assessment of the recoverability - Journal of Cleaner Production - Vol. 2008, n¹6, p.277-298 - 2006 


\title{
ReSICLED: a new recovery-conscious design method for complex products based on a multicriteria assessment of the recoverability
}

\author{
Fabrice Mathieux $^{\mathrm{a}, *}$, Daniel Froelich $^{\mathrm{b}}$, Pierre Moszkowicz ${ }^{\mathrm{c}}$ \\ ${ }^{a}$ Centre of Research and Interdisciplinary Studies on Sustainable Development, Troyes University of Technology, \\ 12 Rue Marie Curie, BP 2060, F-10010 Troyes Cedex, France \\ b Institute Design, Mechanical Engineering and Environment, ENSAM Chambéry, Savoie Technolac, BP 295, \\ F-73375 Le Bourget-du-Lac Cedex, France \\ c Laboratoire d'Analyse Environnementale des Procédés et Systèmes Industriels, INSA Lyon, Bât. Sadi Carnot, \\ 9 Rue de la Physique, F-69621 Villeurbanne Cedex, France
}

\begin{abstract}
Significant improvements in end-of-life complex product recovery can be accomplished when recovery aspects are better integrated at the design stage of products. This paper introduces a new method that should allow design teams to produce better recovery-conscious designs, i.e. to integrate the complexity and the variability of recovery routes and to make recoverability more tangible to designers. The main methodological aspects of the new method are presented based on an analysis of the strengths and weaknesses of existing methods. In particular, the original multiprocess modelling of recovery scenarios and the original quantitative, multicriteria and multiscenario assessment of the recoverability of a product are detailed. On the basis of the assessment results, a design team is able to suggest design improvements. The implementation of the new method is simulated in real industrial practice. It is shown how the use of the method can bring significant gains in the product's recoverability. Assets and drawbacks of the method are discussed.
\end{abstract}

Keywords: Product recoverability/recyclability; Recovery route complexity and variability; Waste; Electric and electronic equipment; Multicriteria; Design for environment; Ecodesign

\section{Introduction}

Complex products, e.g. automotive vehicles and electric and electronic equipment (EEE), have been identified by the European Union as priority waste streams [1]. This is due to their growing proportion in the total waste stream and the presence of pollutants and of valuable materials.

In particular, waste of electric and electronic equipment (WEEE) is already covered by a European Directive adopted in 2002 [2]. After this Directive, manufacturers are now responsible for the treatment and the recovery of their products: they should take on a large part of the economic burden of the

\footnotetext{
* Corresponding author. Tel.: +33 3257185 48; fax: +33 325717698 . E-mail address: fabrice.mathieux@utt.fr (F. Mathieux).
}

recovery, facilitate the development of efficient recovery routes and make sure that specific recovery rates per weight are met. The Directives also contain some incentives for the manufacturers to ensure that the design of their products integrates end-of-life recovery aspects. At the same time, consumers and NGOs put pressure on producers, e.g. through questions in questionnaires or criteria in ecolabels (cf. [3]), to guarantee that the design of their products is appropriate in an end-of-life perspective.

In order to improve the recovery of products at the end of their life, two strategies can be implemented by manufacturers [4]:

- either curative action, i.e. promoting technical and economic development and improvement in recovery processes to be applied to products at the end of their life, 


\section{List of acronyms}

\begin{tabular}{ll} 
ABS & Acrylo-butadiene-styrene \\
CRT & Cathode Ray Tube \\
DCD & Dismantling-Conscious Design \\
DRCD & Dismantling for Recovery-Conscious Design \\
EEE & Electric and Electronic Equipment \\
EIRI & Environmental Impact Recoverability Indicator \\
& according to impact category I \\
ERI & Economic Recoverability Indicator \\
GW & Global Warming \\
HIPS & High Impact Polystyrene \\
HIPS-Ad High Impact Polystyrene with additive \\
IO & Improvement Opportunity \\
IR & Input Requirements \\
MI & Main Inputs \\
MO & Main Outputs \\
PA66 & Polyamide 66 \\
PC & Polycarbonate \\
PDP & Product Development Process \\
PP & Polypropylene \\
PWB & Printed Wiring Board \\
RCD & Recovery-Conscious Design \\
ReSICLED Recovery Systems modelling \& Indicators \\
& Calculation Leading to End-of-Life-conscious \\
& Design \\
RMD & Raw Material Depletion \\
RSCD & Recovery System-Conscious Design \\
SCD & Shredding-Conscious Design \\
SI & Secondary Inputs \\
SO & Secondary Outputs \\
WE & Water Eutrophication \\
WEEE & Waste of Electric and Electronic Equipment \\
WRI & Weight Recovery Indicator \\
\hline &
\end{tabular}

- or preventive action, i.e. improving, through better design, the product's recoverability; this preventive strategy, often called Design for Recycling, concerns the team in charge of the design of a product and is called in this paper recovery-conscious design (RCD).

The recoverability of a product is defined in this paper as its ability to be recovered, i.e. the ability of the product, its components and the constitutive materials either to be reused, or to be recycled, or to be recovered as energy. The two coexisting strategies are in fact complementary, as pointed out by C. Coppens during his research on the recoverability of automotive products, "curative action is only optimised if it is completed by adapted preventive action" [5]. The aim of any RCD method is indeed to ensure the appropriateness of the product to the recovery processes which are applied at the end of its life [6].

Today, the end-of-life recovery of complex products is often seen by non-specialists, e.g. product designers, as just the activity of manual dismantling. However, after a survey of the activities of recovery of EEE and vehicles in Europe, the USA and Japan, we have shown that recovery is in reality a system of many different processes, including in particular: manual dismantling, shredding, material sorting, recycling and even marketing recycled materials [7]. As argued by A. van Schaik for end-of-life vehicles, recycling of end-of-life products "involves a network of interconnected processes" [8].

Recovery of EEE is today characterised at the European level by great geographic variability. From a quantitative point of view, the amount of WEEE currently treated fluctuates from $4 \mathrm{~kg}$ per habitant per annum in some countries, e.g. Germany and Sweden, to less than $1 \mathrm{~kg}$ per habitant per annum in others, e.g. Greece and Hungary [9]. From a qualitative point of view, the recovery of EEE varies as well: N. Nagel shows for example that shredding strategies are usually encountered as the first step of recovery in Germany and in the Netherlands, while manual dismantling is preferred in Sweden [10].

The recovery of EEE is also strongly dynamic. From a quantitative point of view, the amount of treated products should rise dramatically in the coming years after implementation of the European Directive. From a qualitative point of view, the activity is greatly stimulated by technological innovations. For example, in today's recovery activity, most of the parts made of plastic, extracted from EEE, are sent to controlled landfill or incinerators. However, plastic-sorting technologies are still being developed, e.g. Raman Infrared identification [11], froth flotation sorting [12] and triboelectric sorting [13]. In the next few years, these technologies will probably contribute to diverting the EEE plastics from their current destinations. Considering that the life of much EEE is long, these innovations are particularly relevant for today's product design activities.

This paper aims at introducing a new recovery-conscious design method for complex products and at showing its benefits through its application to a case study. Section 2 presents a review of the literature and consists in analysing and classifying some of the methods available. It leads to the formulation of a need. After an overview of the method presented in the third section, the modules of the method are detailed in Sections 4 and 5. In the Section 6, a full case study in which the method is applied to an existing product for the improvement of its design is presented. This leads to the paper's last section where the benefits and drawbacks of the method are discussed.

\section{Review of tools for recovery-conscious design}

Recovery-conscious design (RCD) is not a new area as it has been approached for more than a decade. Some tools and methods for RCD already exist and are used by product manufacturers. This section contains an analytical analysis of some of these tools and methods that have been found relevant for our research. In the following paragraphs, they are examined according to four main characteristics:

- the recovery processes that are considered and the way they are modeled; 
- the ability of the method to integrate uncertainties concerning recovery routes;

- the recoverability criteria considered;

- the ability of the method to be used during the product's design process.

While emphasising the necessity to categorise tools and methods, it should be pointed out that many of them are flexible and not always well defined. The characteristics discussed in this section may be seen as endpoints on scales where many tools and methods can take several positions.

\subsection{Recovery processes considered}

Within RCD, several groups of methods can be differentiated according to the types and numbers of processes that are considered in the recovery system and the way to model them. We now classify tools and methods in the four following groups: dismantling-conscious design (DCD), dismantling for recovery-conscious design (DRCD), shredding-conscious design (SCD) and recovery system-conscious design (RSCD).

Methods for DCD aim at ensuring the appropriateness of the product to manual dismantling. They can be used for other purposes than only increasing the product's end-oflife recoverability, in particular to increase its maintainability and its upgradeability, two criteria that are gaining interest with the emergence of product-service-system oriented strategies.

For example, the VDI 2243 standard qualitatively establishes the ability of several fastening alternatives to be dismantled [14]. A software tool developed for the automotive and electr(on)ic sector in the early nineties and called ReStar helps a design team to optimise the dismantling sequences of a product [15]. Research carried in UK led to setting up a list of DCD guidelines concerning materials, fastenings and architecture to be applied to products $[16,17]$. Such guidelines have been adapted for the electronic sector, for example in Ref. [18].

Considering the broad context of the recycling of complex products, DCD tools and methods seem insufficient because [7]:

- the recovery is reduced to just dismantling,

- they imply poor understanding of the general context of recovery, which includes a complex mix of processes and is characterised by large geographical and temporal variation.

Methods for DRCD consider that manual dismantling is not the only process applied to an end-of-life product but the first: the dismantling operation aims at preparing the product for the downstream recovery routes.

For example, the Recyclability Map proposed by B.H. Lee and K. Ishii aims at modifying product design so that the number of recovery routes after dismantling is minimised [19]. The dismantling planning software tool called DfE assists assessment of the economic and environmental effects of each step of dismantling a product [20]. Other software tools currently used in the industry, e.g. GDA [21,22] and ATROiD [23], have a very similar methodological basis.

However, the DRCD methods seem insufficient in the sense that [7]:

- the recovery routes are modelled on an aggregated form and therefore can integrate neither the exact performance of the downstream processes nor their evolutionary changes in the future;

- they imply poor understanding of the general context of recovery.

Approaches for SCD consider that shredding operations can be a valuable alternative to manual dismantling operations. They claim that the design of a product should be oriented so that parts and materials obtained after shredding the product are easily recovered.

For example, W. Knight and M. Sodhi argue that the economic viability of recovery based on an initial dismantling operation is not guaranteed and the product should instead be oriented to shredding processes coupled with sorting processes [24]. Separability guideline tables such as the ones proposed by AFNOR [25] and Hundal [26] are typically SCD tools. Some automotive equipment manufacturers already encourage the use of polypropylene as this material can be easily sorted after shredding and gravimetric sorting [27]. However, this approach seems too simplistic as polypropylene will hardly be the only resin used in complex products in the future. SCD methods should hence be developed further in order to consider additional sorting technologies and therefore a large range of plastic materials. After studying comminution and liberation phenomena during the end-of-life shredding of vehicles, recent SCD approaches focusing on metallic materials show that materials and joints among them can be chosen at the design stage to facilitate the product's end-of-life recovery $[8,28]$. However, these findings can currently hardly be used for the design of products as authors argue that the approach is "a first step" and that much experimental work is required for further development.

Even though promising, the SCD methods still seem insufficient because initial dismantling and depollution stages are not considered and because they are recent and still incomplete [7].

Research in RCD has been recently oriented to RSCD methods that acknowledge the recovery of a product as a combination of processes such as dismantling, shredding, sorting, and recycling [29]. Such an approach has been initially defended by the automotive industry (see e.g. Refs. [5,30]). This has been made concrete for example in the proposal for calculation of recoverability indicators for automotive vehicles [31]. In this method, the number of processes considered remains limited, however. The recycling module of the software tool euroMat' can be classified as a RSCD tool: all recovery strategies are addressed, e.g. re-use, recycling and energy recovery, and a systemic approach, including technology and market availability, is adopted [32]. However, this tool can only guide the choice of material and the recovery routes 
are aggregated and therefore cannot integrate the complex mix of processes of the recycling system.

Considering that product recovery is a systemic activity, as described in Section 1, we believe that it is indeed towards the RSCD group that research in recovery-conscious design should be oriented. The RSCD methods are actually a mix of DCD, DRCD and SCD approaches: DCD and DRCD tools can be used to facilitate disassembly of products when it is needed; SCD tools can be used when shredding of the product seems more likely than dismantling. The tools and methods identified in this section and in the following sections are graphically classified in these four groups in Fig. 1.

\subsection{Ability to integrate uncertainties concerning recovery routes}

Many EEE products have a long life and will only be recovered 5-20 years after their design. Also, they are now commercialised throughout the whole European continent. This implies that the recovery routes that will be applied to the products at the end of their life are characterised by two main uncertainties:

- one is geographical and is caused by the disparity of treatment between countries;

- the other is temporal and is caused by the evolution of recovery technologies that takes place during the lifespan of the product.

During our literature review, it was not possible to identify any RCD method that explicitly takes into account the geographic uncertainties: recovery routes are usually considered available everywhere.

Some RCD methods take into account temporal uncertainties. Some of the recoverability indicators for automotive products described in Ref. [6] do so: for example, those proposed by Chrysler and AAMA contain criteria concerning anticipated technological development and economic viability of recovery routes. The recoverability indicators proposed by

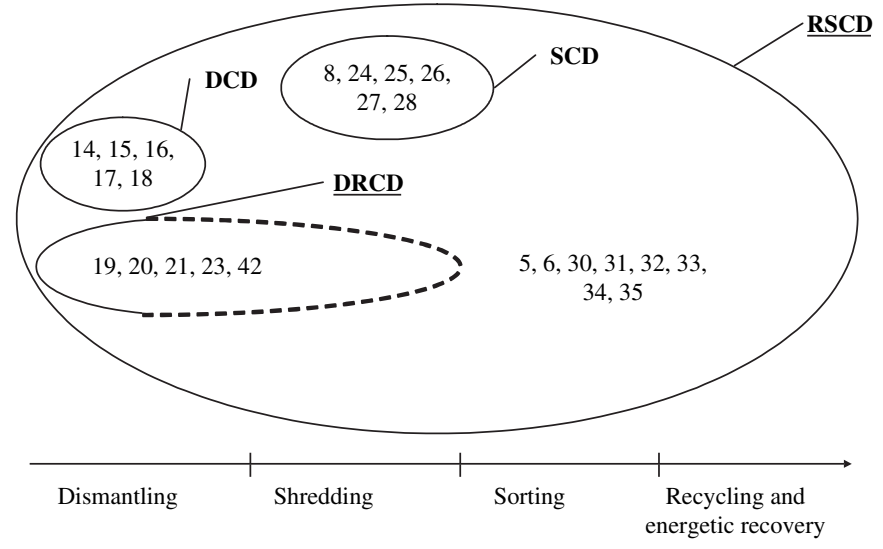

Recovery processes considered in the recovery system

Fig. 1. Graphical classification of RCD methods in four groups according to the recovery processes considered in the recovery system. Methods are identified with the reference in which they are described. the ISO consider the so-called "recognised" sorting and recycling technologies, i.e. those that "have been tested with success, at least on the laboratory scale" [31]. However, no criterion to decide whether a technology has been successful is stated and the method remains therefore little transparent.

The software tool euroMat' [32] as well as other recent RCD methodologies and tools, e.g. the QWERTY method [33], Herrmann's approach [34] or the tool DfE2 [35] claims that they can integrate prospective recovery routes. However, only data contained in databases in an aggregated form are concerned. Moreover, no description of the nature of the prospective data and the way to collect it is provided in these publications.

\subsection{Recoverability criteria considered}

The main driving forces for the development of end-of-life product recovery activity have been legislative pressure and economic profit. For this reason, weight and economic criteria are widely considered in today's RCD methods [7].

While EU legislation only sets objectives for recovery rates per weight [2], it is primarily aiming at pollution reduction, the conservation of resources and management of dangerous substances [36]. As pointed out by D. Navin-Chandra the product recovery problem "is a balance between polluting emissions, cost, energy consumption and environmental impact" [15]. So far, few RCD methods have dealt with the actual environmental impact and environmental benefits of recovery of a product. Some RCD methodologies like the $D f E$ method [20], the QWERTY method [33] or the Herrmann approach [34] aim at establishing the real environmental significance of the product's recovery using the Life Cycle Impact Assessment methodology. Despite these recent attempts, the environmental performance of product's recovery is a key criterion that has been so far too little addressed. Moreover, only one software tool, Demrop, integrates health and safety criteria for those carrying out recovery [37].

\subsection{Ability to be used during the product development process}

\subsubsection{Product's environmental performance and product development process}

To be effective, any ecodesign methodology should not only be based on environmental performance assessment but should also help a design team to identify improvement opportunities [38,39]. When associating tools with the Product Development Process (PDP), it should in addition efficiently answer the design team's questions. Many standardisation publications claim that the environmental criteria, in particular the end-of-life recovery aspects, should be integrated as soon as possible and at all the stages of the design process $[40,41]$. However, the integration of most RCD methods into the design process has been little addressed. Among the RCD methods identified in Ref. [7], some can be used:

- either at the end of the design process, to choose among several designs, 
- or during the detailed design phases to choose among design alternatives, e.g. euroMat', the MMU guidelines, the separability tables,

- or throughout the whole project, from the planning phases to the product's commercialisation, e.g. the Re-design for Recycling method [42] or the automotive indicators Functional Recovery Ability, FRA [5].

Furuhjelm [29] points out that recovery aspects are little addressed during the design of a product as they remain "intangible and difficult to understand for a design team". Indeed, many of the RCD tools and methods discussed earlier, in particular DCD guidelines are only qualitative in the sense that they give general directions for improvement but do not explicit how much the design should be improved. Even if some research showed that quantitative method are not always better than qualitative methods [38], there is indeed a strong need to develop some original scientific quantitative assessments of the recoverability of a product that could be used by design teams. These assessments have to be simple enough to be understood by design teams and sufficiently worked out to follow the product's performance efficiently during the design reviews [43]. Considering that qualitative methods, e.g. the DCD guideline "reduce the number of fastenings", can route designers towards preestablished solutions, an appropriate quantitative assessment would have the benefit of leaving more freedom to designers who could find other design improvement opportunities, for example "choose another type of fastening".

\subsubsection{Attributes influencing the product's recoverability}

Many DCD and DRCD methods discussed earlier imply design lessons that only concern fastening and dismantling precedence issues. Inversely, SCD tools like separability tables usually only focus on the choice of materials. Some of the RSCD approaches described earlier argue that the recoverability of a product not only depends upon fastening, architecture issues and material choice, but also on the combination of materials and joints among them [28], and on many other aspects like the economic value of virgin and secondary materials [27], the availability of technology [31] or the environmental impacts of the production of virgin materials [32]. A product development team is usually composed of several experts of specific product attributes [44], e.g. experts for metallic casing, plastic casing, fastening techniques, or painting techniques, and there is indeed a need to consider all possible attributes of a product that could influence its recoverability so that the team can make the best choices.

\subsection{Conclusion of the review}

The literature reveals that many different attributes of a product can influence its recoverability. It is already possible to form three groups of attributes:

- attributes of the material, e.g. the type of material;

- attributes of the fastening between parts, e.g. the type and number of fastenings;
- attributes of the architecture of the parts and the product, e.g. the precedence rules between parts.

All RCD methods have assets but they all also have limitations and none of the methods identified are able to lead to the efficient and complete recovery-conscious design of complex products. Table 1 sums up the analysis of four RCD methods that has been carried out in this section. A similar analysis of 25 RCD methods can be found in Ref. [7].

This literature review leads to the formulation of the following need: "There is a need to develop an innovative method that could help a design team improve the ability of the product to be recovered in a context of great uncertainty concerning recovery routes". This original method should in particular:

- lead to a quantitative assessment of recoverability of a product according to all relevant criteria,

- be based on modelling the reality of product and materials recovery activity at the end-of-life,

- integrate the geographical as well as temporal uncertainties concerning the recovery routes, and

- be usable by design teams in order to orientate decisionmaking.

A design team is here defined as a group of designers that are experts on one or several attributes of the product and who control the product's design.

The next sections of this paper describe a new RCD method that has been set up in order to satisfy this need.

\section{Overview of a new recovery-conscious design method}

The aim of this paper is to present in detail a new RCD method, called Recovery Systems modelling and Indicator Calculation Leading to End-of-life-conscious Design, or ReSICLED. This method has been previously presented in a $\mathrm{PhD}$ thesis [7].

The ReSICLED method was set up in order to satisfy the product manufacturer's requirements that were identified during consultation of several electric and electronic equipment manufacturers and one automotive manufacturer. Manufacturers require in particular that [44]:

- scientific and quantitative assessments of the ability of a product to be recovered are suggested;

- concrete guidelines to be applied by the design team can be obtained;

- design solution space is kept as large as possible and the creativity of the design team is trusted.

The method was set up after an in-depth study of recovery activity, established after extensive surveys of EEE and automotive vehicle recycling activities in Europe, the USA and Japan carried out from 2000 to 2002 and compiled in Ref. [44]. The main objectives of these surveys were as follows:

- to collect data concerning the processes/route performance; 
Table 1

Qualitative analysis of four recent RCD methods

\begin{tabular}{|c|c|c|c|c|}
\hline \multirow[t]{2}{*}{ Analysis criteria } & \multicolumn{4}{|c|}{ Name of the RCD methods } \\
\hline & euroMat' & ATROiD & FRA & QWERTY \\
\hline $\begin{array}{l}\text { Recovery processes } \\
\text { and systems considered (RCD group) }\end{array}$ & $\begin{array}{l}\text { Aggregated recovery } \\
\text { routes }(\mathrm{RSCD})\end{array}$ & $\begin{array}{l}\text { Manual dismantling } \\
\text { followed by aggregated } \\
\text { recovery routes (DRCD) }\end{array}$ & $\begin{array}{l}\text { Manual dismantling } \\
\text { and shredding followed } \\
\text { by aggregated recovery } \\
\text { routes (RSCD) }\end{array}$ & $\begin{array}{l}\text { Non-aggregated recovery } \\
\text { routes (RSCD) }\end{array}$ \\
\hline \multicolumn{5}{|c|}{ Ability to integrate uncertainties of recovery routes } \\
\hline Geographic & $0^{\mathrm{a}}$ & 0 & 0 & 0 \\
\hline Temporal & $(\boldsymbol{\nu})^{\mathrm{b}}$ (in database) & 0 & $(\boldsymbol{})$ (subjective) & $(\boldsymbol{\swarrow})$ (in database) \\
\hline \multicolumn{5}{|l|}{ Recoverability criteria considered } \\
\hline Per weight & 0 & 0 & $\boldsymbol{\nu}^{\mathrm{c}}$ & $(ん)$ \\
\hline Economic & レ & 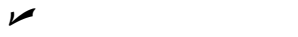 & 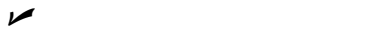 & 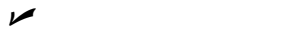 \\
\hline Environmental & $(\boldsymbol{L})$ & 0 & 0 & 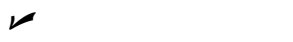 \\
\hline \multicolumn{5}{|c|}{ Ability to be used during the product development process } \\
\hline Product attributes & Material & $\begin{array}{l}\text { Material, architecture } \\
\text { and geometry, fastening }\end{array}$ & Material, architecture, fastening & Material \\
\hline Integration into the design process & $\nu$ & $(\boldsymbol{})$ (assessment only) & 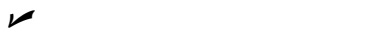 & $(ん)$ (assessment only) \\
\hline References & [32] & [23] & {$[5,43]$} & [33] \\
\hline
\end{tabular}

a Not integrated.

b Partially integrated.

c Widely integrated.

- to collect the feelings of those involved and their vision of the future of the activity;

- to understand the general context of recovery activity.

The ReSICLED method includes the following main features:

- the ability of a product design option to be recovered at the end of its life is assessed by the design team on a quantitative basis according to several recovery scenarios and several recoverability criteria;

- analysis of the recovery assessment helps the design team to identify design improvement opportunities;

- the design improvements can be implemented and the product design modified.

The synoptic diagram of the method is presented in Fig. 2. Numbering of the sections of the paper that described each module of the method is given in the same figure.

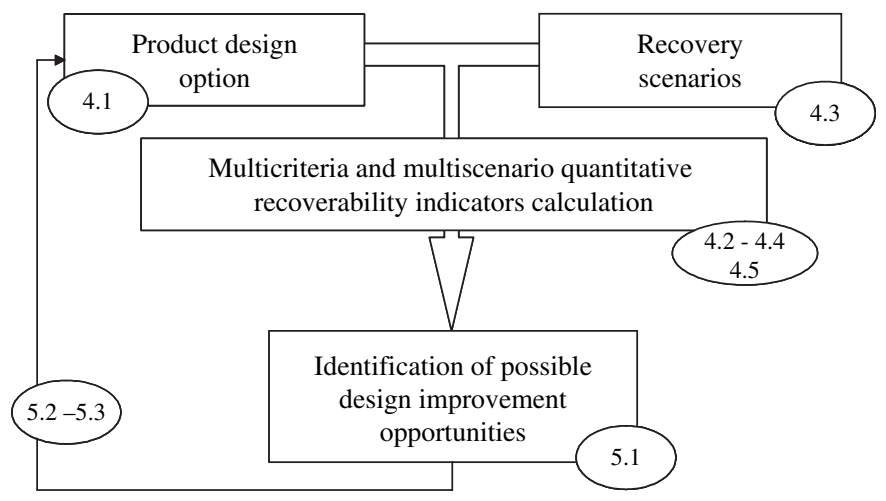

Fig. 2. Synoptic diagram of the ReSICLED method.

\section{Quantitative assessment of the recoverability of a product}

\subsection{Modelling a product}

Attributes of the material, of the fastening between parts and of the architecture of the parts and the products have to be defined for a product to be assessed by the ReSICLED method.

\subsection{Criteria for recoverability}

Legislative pressure, the reduction of costs and the corporate image are often identified as the main driving forces for the implementation of ecodesign practices in companies [38]. Applying such principles to the recovery issue, we identify the following three relevant criteria for recoverability assessment of a product at its design phase:

- The weight criterion, to meet legislative requirements established by the European Parliament [2];

- The economic criterion, to ensure cost control during the implementation of the WEEE Directive requirements;

- The environmental criterion, to guarantee the corporate image of the company as well as to cope with new legislation (e.g. Ref. [45]).

The criteria are considered distinct. Moreover, no prioritisation of the criteria is a priori adopted. The content of each of these criteria is described in the following paragraphs. Considering these three criteria means the approach can be included in the context of sustainable use of natural resources and the 
reduction of pollution, as defined by the European Union [36]. It should in particular lead to:

- minimisation of the amount of waste which is landfilled,

- setting up of recovery systems that are economically viable,

- conservation of resources and reduction of pollution.

The weight criterion is a quantitative evaluation of the recovery rate per weight that will be reached from recovery of a product at the end of its life. As proposed in some existing legislative texts (e.g. Refs. $[2,46])$, the recovery rate, including part re-use, material recycling and energy recovery, and the recycling rate, including part re-use and material recycling, are differentiated. The legislative requirements on recovery rates differ for all electronic equipment categories, as established by the European Parliament [2]. There have been some attempts to define a procedure for calculating such rates (e.g. Ref. [31]). However, none are currently fully acknowledged and our own calculation procedure will be described. The weight criterion is environmental as it is linked to the quantity of residual waste going to the landfill. However, with future legislation (e.g. Ref. [47]), the weight criterion is also a legislative criterion for producers, which they comply or do not comply with.

The economic criterion is a quantitative evaluation of the overall cost - or the economic benefit - of recovery of the product, as it is paid - or earned - by the last owner of the product. This cost - or benefit - includes the cost of collecting and processing the product and the economic benefits obtained when selling recycled materials and recovered energy that are produced.

The environmental criterion is a quantitative assessment of the overall environmental impact - or benefit - of recovery of the product at the end of its life. It includes the environmental impact of collecting and processing the product and the environmental benefits associated with the use of recycled materials and recovered energy in downstream life cycles.

\subsection{Multi-process modelling of recovery scenarios}

A recovery scenario is modelled as a consistent combination of elementary recovery processes. A recovery scenario converts an end-of-life product into recycled material, recovered energy and residual waste.

Each elementary recovery process, for example a process of dismantling, shredding, sorting or recycling, converts the main inputs (MI) extracted from the end-of-life product into main outputs (MO). Meanwhile, an elementary process consumes secondary inputs (SI) and discharges secondary outputs (SO), which are peculiar to the process. To be treated by a process, a main input has also to respect the process' requirements, which are called input requirements (IR).

The aspects of modelling a recovery scenario and the associated notations are presented in Fig. 3.
This modelling makes it possible to take into account the performance of each process and its possible progress in the future. It also allows the recovery activity to be considered from a systemic point of view.

During our research, we modelled eight types of elementary recovery processes that are currently observed during the recovery of EEE: manual dismantling; shredding; sorting; recycling; incineration with energy recovery; selling recycled materials and recovered energy; burying in controlled landfill; and logistics. The purpose(s) and the main inputs-outputs of each of these generic recovery processes are established in Table 2.

The ReSICLED modelling of an elementary recovery process links:

- the main outputs to the main inputs and functional performance of the process, i.e. to what extent the process performs its purpose;

- the quantity of waste generated to the technical performance of the process and to the quantity and quality of the main inputs;

- the costs and benefits of the process to the economic performance of the process and to the quantity and quality of the main inputs;

- the environmental impacts and benefits to the environmental performance of the process and to the quantity and quality of the main inputs.

Moreover, economic and environmental performance of each process is related to its secondary inputs and outputs. $G e$ neric modelling of the elementary processes can be turned into specific modelling when fed by data collected from recyclers. This is illustrated in Table 3 where the elementary processes of dismantling, sorting and recycling are modelled in generic and specific ways. The specific processes are here modelled using some data extracted from the so-called ENSAM database that was compiled after extensive surveys of product recovery routes led during an industrial research project funded by the French Environmental Protection agency, ADEME [44]. Some of these specific processes will be considered in the case study presented in Section 6.

Elementary processes are combined in a coherent way to form a recovery scenario so that:

- the main outputs of a process $i$ respect the input requirements of the process $i+1$;

- the product is fully recovered or treated;

- the constructed scenario can possibly be applied to the product at the end of its life, i.e.:

$\circ$ either it is already available and applied to the end-oflife product,

○ or it is very likely, e.g. according to experts, that it will be available in the future.

More information about the original modelling of end-oflife product recovery scenarios and of recovery processes can be found elsewhere [7]. 


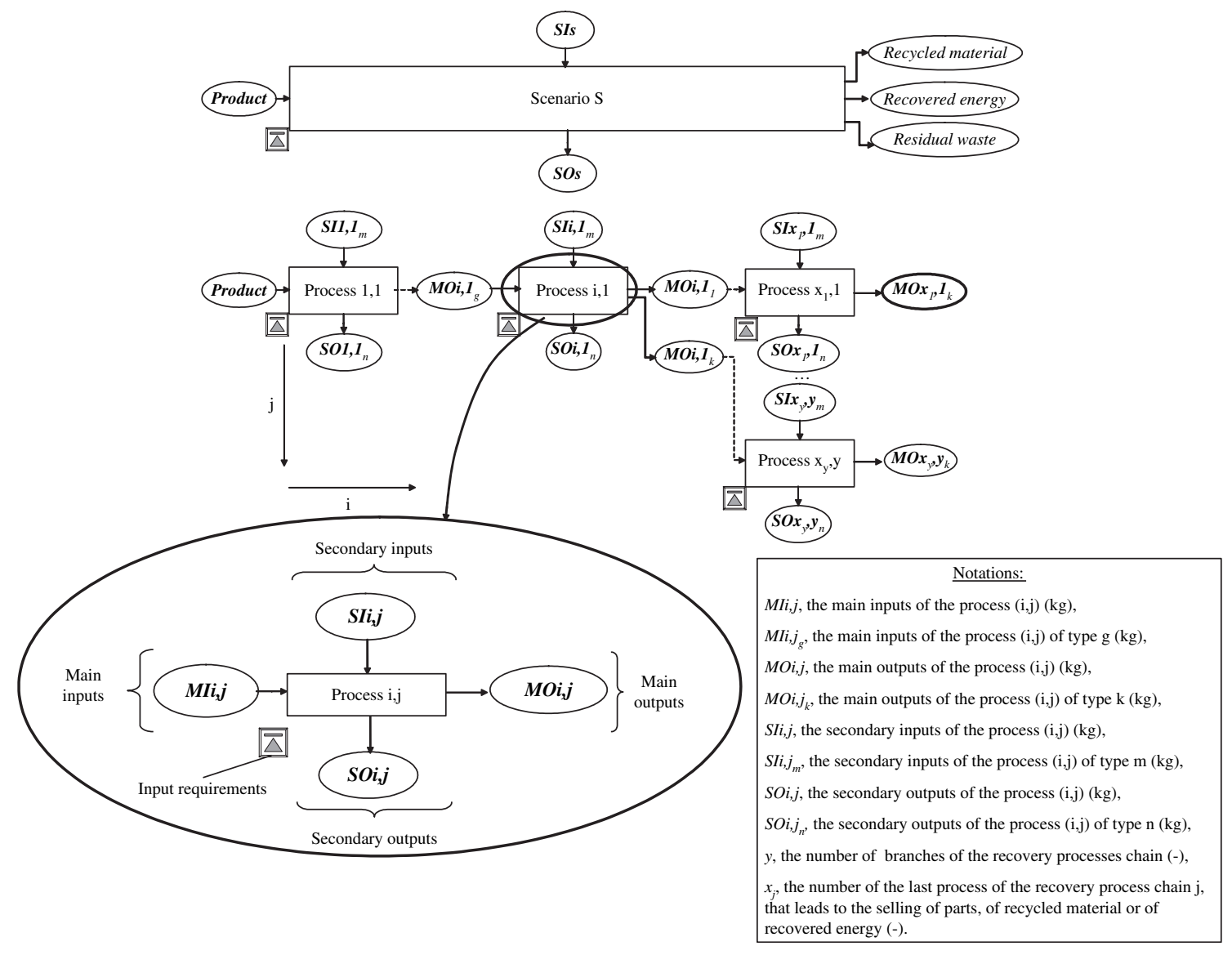

Fig. 3. Modelling a product's recovery scenario as a combination of the modelling of elementary recovery processes.

\subsection{A multicriteria recoverability assessment}

As expressed earlier, the recoverability of a product is quantitatively assessed according to three distinct criteria. We define the recoverability indicators as follows:

- The Weight Recovery Indicator, WRI, is the proportion, expressed in $\%$, of the weight of the product that is recovered. A distinction is made between $\mathrm{WRI}_{\text {Recovery, that is }}$ the proportion recovered and $\mathrm{WRI}_{\text {Recycling }}$, that is the proportion recycled;

- The Economic Recoverability Indicator, ERI, expressed in $€$ per product is the overall economic benefit (when $>0$ ) recovery of the product. The environmental impact categories are those considered in the Life Cycle Impact Assessment methodology.

According to this definition and the notations of Fig. 3, the mathematical formulae of the three indicators are presented in the Eqs. (1)-(4).

$\mathrm{WRI}_{\text {Recovery }}=\frac{\text { Product_weight }-\sum_{j=1 ; y ; i=1, x_{j}} \mathrm{MO} i, j_{\text {Waste }}}{\text { Product_weight }}$

$\mathrm{WRI}_{\text {Recycling }}=\frac{\left.\text { Product_weight }-\sum_{j=1 ; y ; i=1, x_{j}} \mathrm{MO} i, j_{\text {Waste }}+\sum_{j=1, y ; i=1, x_{j}} \mathrm{MO} i, j_{\text {Energy }}\right)}{\text { Product_weight }}$

or the cost (when $<0$ ) of the recovery of the product at the end of its life;

- The Environmental Impact Recoverability Indicator, $\mathrm{EIRI}_{I}$, expressed in the units relative to environmental impact category $I$, is the overall environmental benefit (when $>0$ ) or the overall environmental impact (when <0) of the

$$
\begin{aligned}
\mathrm{ERI}= & \sum_{j=1, y} \mathrm{MO} x_{j}, j_{k} \times \gamma_{k}+\sum_{j=1, y} \sum_{i=1, x_{j}}(\mathrm{MI} i, j \times \mathrm{CP} i, j \\
& \left.\left.+\mathrm{MO} i, j_{\text {waste }} \times \gamma_{\text {waste }}\right)\right)
\end{aligned}
$$


Table 2

Purpose(s) and main inputs-outputs of eight elementary recovery processes (according to Ref. [7])

\begin{tabular}{|c|c|c|c|}
\hline Recovery process & Purpose(s) of the process & Main inputs & Main outputs \\
\hline Manual dismantling & $\begin{array}{l}\text { - Extracting elements to be recovered } \\
\text { - Extracting elements which could } \\
\text { hinder downstream recovery processes }\end{array}$ & $\begin{array}{l}\text { - Product } \\
\text { - Group of parts }\end{array}$ & $\begin{array}{l}\text { - Parts to be further } \\
\text { recovered or treated }\end{array}$ \\
\hline Shredding & $\begin{array}{l}\text { - Liberating materials and parts } \\
\text { - Reducing part/particle size and volume }\end{array}$ & $\begin{array}{l}\text { - Product } \\
\text { - Parts }\end{array}$ & $\begin{array}{l}\text { - Particles of different } \\
\text { materials } \\
\text { - Particles of a single material }\end{array}$ \\
\hline Sorting & $\begin{array}{l}\text { - Creating concentrated material mix } \\
\text { - Extracting elements which could hinder } \\
\text { downstream recovery steps }\end{array}$ & $\begin{array}{l}\text { - Mix of parts } \\
\text { - Mix of particles }\end{array}$ & $\begin{array}{l}\text { - Sorted parts } \\
\text { - Sorted particles }\end{array}$ \\
\hline Recycling & $\begin{array}{l}\text { - Producing and selling recycled materials } \\
\text { that meet users' requirements }\end{array}$ & - Concentrated mix of particles & $\begin{array}{l}\text { - Recycled material ready to } \\
\text { be used in a downstream } \\
\text { life cycle }\end{array}$ \\
\hline $\begin{array}{l}\text { Incineration with } \\
\text { energy recovery }\end{array}$ & $\begin{array}{l}\text { - Destroying harmful substances } \\
\text { - Reducing the volume of waste } \\
\text { - Producing recovered energy }\end{array}$ & $\begin{array}{l}\text { - Parts/components } \\
\text { - Particle mix }\end{array}$ & $\begin{array}{l}\text { - Energy } \\
\text { - Residual waste }\end{array}$ \\
\hline $\begin{array}{l}\text { Selling recycled materials } \\
\text { and recovered energy }\end{array}$ & $\begin{array}{l}\text { - Feeding the market with recycled } \\
\text { materials and recovered energy }\end{array}$ & - Recycled material/recovered energy & $\begin{array}{l}\text { - Recycled material/recovered } \\
\text { energy used in downstream } \\
\text { life cycles }\end{array}$ \\
\hline Burying in controlled landfill & - Storing residual waste safely & - Residual waste & - No outputs \\
\hline Logistics & $\begin{array}{l}\text { - Transferring materials/elements } \\
\text { from one recovery site to another }\end{array}$ & - Products/parts/particles (on a site) & $\begin{array}{l}\text { - Products/parts/particles } \\
\text { (on another site) }\end{array}$ \\
\hline
\end{tabular}

$\mathrm{EIRI}_{I}=\frac{\left.\sum_{j=1, y} \mathrm{MO} x_{j}, j_{k} \times \eta \mathrm{IP}_{k}-\sum_{j=1, y} \sum_{i=1, x_{j}}\left(\mathrm{SI} i, j_{m} \times \eta \mathrm{IP}_{m}+\mathrm{SO} i, j_{n} \times \eta \mathrm{IE}_{n}+\mathrm{MO} i, j_{\text {waste }} \times \eta \mathrm{IE}_{\text {waste }}\right)\right)}{\eta \mathrm{IP}_{\text {product }}}$

where

- Product weight is the mass of the product $(\mathrm{kg})$,

- $M I, M O, S I$, and $S O$ are those defined in Fig. $3(\mathrm{~kg})$,

- $\gamma_{k}$ [GAMMA] is the economic market value of a mass unit of type $k$ material $(€ / \mathrm{kg})$; it can be positive or negative,

- $C P i, j$ is the cost of the process $(i, j)$ per mass unit of input $(€ / \mathrm{kg}) ; C P i, j$ includes the cost of the process itself but also overheads and benefits of the company running the process; it is negative,

- $\eta I P_{m}[\mathrm{NU}]$ is the environmental impact according to impact category $I$ of the production of a mass unit of type $m$ material (unit of environmental impact $/ \mathrm{kg}$ ); it is negative,

- $\eta I E_{n}$ is the environmental impact according to impact category $I$ of the emission of a mass unit of type $n$ mate$\mathrm{rial} / \mathrm{substance}$ (unit of environmental impact $/ \mathrm{kg}$ ); it is negative,

- $\eta I P_{\text {product }}$ is the environmental impact according to impact category $I$ of the production/manufacture of the product (unit of environmental impact $/ \mathrm{kg}$ ); it is negative,

- $y$ and $x_{j}$ are those defined in Fig. $3(-)$.

The indicators are algebraic sums of the positive and negative impacts of the processes on the product's multicriteria recoverability.
The WRI is calculated when totalling up the quantities of waste generated and quantities of materials transformed into energy by all the processes of the scenario.

The ERI is the subtraction of the economic benefits, associated with selling recycled materials/recovered energy, from the costs of all the processes. The first term of the equation represents the benefits associated to the selling of the main output of the chain's last process to the market; the first term between brackets represents the cost of process $(i, j)$; and the second term between brackets represents the cost associated to the safe treatment of waste produced by process $(i, j)$. Costs/benefits for actor $(i, j)$ of transferring its output to actor $(i+1, j)$ and benefits/costs for actor $(i+1, j)$ of acquiring input from actor $(i, j)$ do not appear in the equation as they are opposite and therefore offset each other.

The numerator of the $\mathrm{EIRI}_{I}$ is the subtraction of environmental benefits, associated with the use of recycled materials/recovered energy in further product life cycles, from the environmental impact of all the processes. The first term of the numerator represents the environmental benefits associated to the use of the main output of the chain's last process in other applications, in replacement of virgin materials; the first term between brackets represents the environmental impact associated to the consumption of secondary inputs by process $(i, j)$; the second term between brackets represents the environmental impact associated 
Table 3

Generic and specific modelling of three elementary recovery processes

\begin{tabular}{|c|c|c|c|c|c|c|c|}
\hline Type & Process & Purpose & Input requirements & Functional performance & Generated waste & Cost and benefit & $\begin{array}{l}\text { Environmental impact } \\
\text { and benefit }\end{array}$ \\
\hline Generic & Manual dismantling & $\begin{array}{l}\text { Extracting pollutant } \\
\text { or element to be } \\
\text { recovered }\end{array}$ & $\begin{array}{l}\text { Various, e.g. } \\
\text { dismantlability and } \\
\text { health and safety aspects }\end{array}$ & Element dismantled & Depends & $\begin{array}{l}\text { - Labour cost } \\
\text { - Cost/benefit of } \\
\text { transferring } \\
\text { dismantled elements to } \\
\text { further treatment }\end{array}$ & Insignificant \\
\hline Specific & $\begin{array}{l}\text { Manual extraction } \\
\text { of a CRT from a } \\
\text { TV set }\end{array}$ & $\begin{array}{l}\text { Extracting a CRT } \\
\text { to make its recovery } \\
\text { possible and then } \\
\text { the rest of the TV set }\end{array}$ & Unbroken CRT & $\begin{array}{l}\text { - } \text { CRT } \\
\text { - Screws } \\
\text { - Rest of the TV set }\end{array}$ & None & $\begin{array}{l}\text { - Labour cost }=€ 0.5 / \mathrm{CRT} \\
\text { - Various }\end{array}$ & Insignificant \\
\hline Generic & Sorting & $\begin{array}{l}\text { Creating concentrated } \\
\text { material mix }\end{array}$ & $\begin{array}{l}\text { Various, e.g. presence } \\
\text { of some materials, } \\
\text { minimum concentration } \\
\text { of a material }\end{array}$ & $\begin{array}{l}\text { Quantity and purity } \\
\text { of the main outputs }\end{array}$ & Depends & $\begin{array}{l}\text { - Cost of processing } \\
\text { - Cost/benefit of } \\
\text { transferring } \\
\text { dismantled elements to } \\
\text { further treatment }\end{array}$ & Impact of processing \\
\hline Specific & $\begin{array}{l}\text { Sorting of plastic } \\
\text { particles using } \\
\text { gravimetric sorting }\end{array}$ & $\begin{array}{l}\text { Creating concentrated } \\
\text { fraction of PP }\end{array}$ & $\begin{array}{l}\text { Only shredded } \\
\text { particles are accepted }\end{array}$ & $\begin{array}{l}\text { - PP fraction: } 90 \% \\
\text { recovery of PP } \\
\text { particles with } \\
\text { a purity of } 98 \% \\
\text { - Other fraction: } 0 \% \\
\text { recovery }\end{array}$ & $\begin{array}{l}-10 \% \text { of PP } \\
-100 \% \text { of other } \\
\text { plastic particles }\end{array}$ & Confidential & $\begin{array}{l}\text { Impact concerning } \\
\text { water and energy } \\
\text { consumption }\end{array}$ \\
\hline Specific & $\begin{array}{l}\text { Sorting of plastic } \\
\text { parts by Raman } \\
\text { identification }\end{array}$ & $\begin{array}{l}\text { Creating styrene } \\
\text { plastics (ABS, PC/ABS, } \\
\text { HIPS) according } \\
\text { to type, additives } \\
\text { and colour }\end{array}$ & $\begin{array}{l}\text { - Plastic parts } \\
\text { must be prepared } \\
\text { (either plastic or metal } \\
\text { inserts accepted) } \\
\text { - Plastic part } \\
\text { must have a } \\
\text { weight }>20 \mathrm{~g}\end{array}$ & $\begin{array}{l}\text { All sorted } \\
\text { fractions: } 99 \% \text { of parts } \\
\text { with } 99.9 \% \text { purity }\end{array}$ & $\begin{array}{l}\text { - } 1 \% \text { of styrene } \\
\text { plastic parts } \\
\text { - } 100 \% \text { of other } \\
\text { plastic parts }\end{array}$ & Confidential & $\begin{array}{l}\text { Impact concerning } \\
\text { water and energy } \\
\text { consumption }\end{array}$ \\
\hline Specific & $\begin{array}{l}\text { Sorting of plastic } \\
\text { particles using } \\
\text { froth flotation }\end{array}$ & $\begin{array}{l}\text { Creating concentrated } \\
\text { fractions of PP, } \\
\text { ABS and HIPS }\end{array}$ & $\begin{array}{l}\text { Only shredded } \\
\text { particles are accepted }\end{array}$ & $\begin{array}{l}\text { - PP fraction: } 80 \% \\
\text { recovery of PP } \\
\text { particles with a } \\
\text { purity of } 98 \% \\
\text { - ABS fraction: } 78 \% \\
\text { recovery of the ABS } \\
\text { particles with a } \\
\text { purity of } 98 \% \\
\text { - HIPS fraction: } 83 \% \\
\text { recovery of HIPS } \\
\text { particles with } \\
\text { a purity of } 98 \%\end{array}$ & $\begin{array}{l}\text { - } 20 \% \text { of PP particles } \\
\text { - } 22 \% \text { of ABS particles } \\
\text { - } 17 \% \text { of HIPS particles } \\
\text { - } 100 \% \text { of other particles }\end{array}$ & Confidential & $\begin{array}{l}\text { Impact concerning } \\
\text { water, energy } \\
\text { and chemical } \\
\text { consumption }\end{array}$ \\
\hline Generic & Recycling & $\begin{array}{l}\text { Producing recycled } \\
\text { materials which meet } \\
\text { users' requirements }\end{array}$ & $\begin{array}{l}\text { Various, e.g. presence } \\
\text { of some materials, } \\
\text { minimum concentration } \\
\text { of a material }\end{array}$ & $\begin{array}{l}\text { Quantity and quality } \\
\text { of main outputs }\end{array}$ & Depends & $\begin{array}{l}\text { - Cost of processing } \\
\text { - Benefit of selling } \\
\text { recycled materials }\end{array}$ & $\begin{array}{l}\text { - Impact of processing } \\
\text { - Benefits of using } \\
\text { recycled materials } \\
\text { in further life cycles }\end{array}$ \\
\hline
\end{tabular}



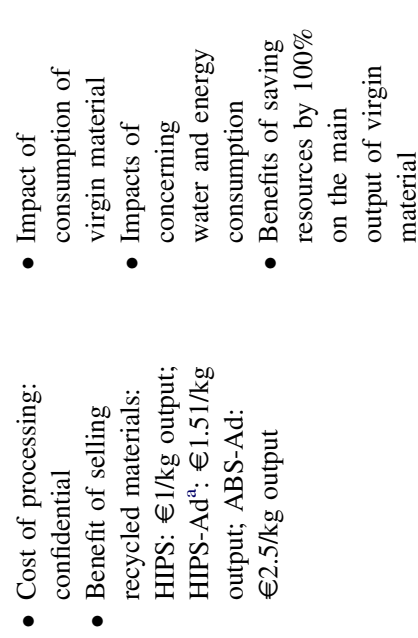

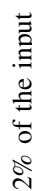

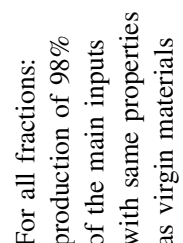

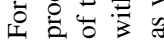
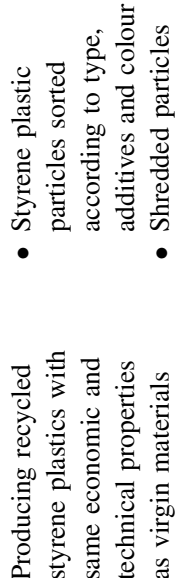

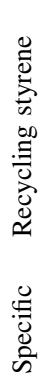

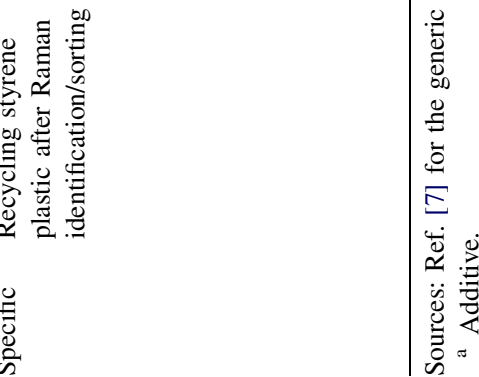

to the emissions of secondary outputs by process $(i, j)$; and the third term between brackets represents the environmental impact associated with the treatment of waste generated by process $(i, j)$.

All calculation procedures for the three indicators, in particular some simplification rules, are not detailed here but have been published elsewhere [7].

\subsection{A multiscenario recoverability assessment}

In order to take into account geographical and temporal uncertainties concerning recovery routes, recovery scenarios are considered in the ReSICLED method as follows:

- Several scenarios are successively considered for the assessment of the product's recoverability;

- The scenarios are chosen within a typology of possible scenarios;

- So-called "prospective technologies", i.e. promising technologies that are still under development but not widely available, can be integrated into some scenarios, which are then called prospective scenarios.

The recovery scenarios should be chosen within a typology of possible scenarios. After extensive surveys of the recovery routes of complex products, it is possible to classify the recovery scenarios according to several criteria, e.g. their availability (e.g. already available/may be available in the future) or their technical properties (e.g. manual dismantling or shredding as a first process) [44]. The scenarios that should be considered when assessing the product's recoverability have to be chosen from among this typology. Such a choice should be made by a recycling expert when considering the questions dealt with during the design phase. For example:

- If the product is to be commercialised throughout the whole European continent, the chosen recovery scenarios have to be representative of the situation encountered in this whole geographical area.

- If the product has a short expected lifespan, e.g. 3 years, only recovery scenarios that will be available at that time should be considered.

- If only the type of material for the plastic parts can be modified at this stage of the PDP, the chosen scenarios should include the most probable recovery routes applicable to the plastic parts.

Considering the diversity of the possible questions faced during the design of a product, the choice of relevant scenarios is left to the discretion of the recycling expert, in accordance with the design team.

\section{Using recoverability assessment to improve the design of a product}

Many environmental assessment tools can be applied to products but they are often more used by environmentalists than by design teams, as it is rarely clear how they can be used in the 
design process [38]. This section aims at establishing how these recoverability assessments can be used by designers to improve the design of a product within the ReSICLED framework.

\subsection{Recoverability assessments in the product development process}

When aiming at improving the design of a product in a recovery perspective, designers using the ReSICLED method should seek to maximise the three recoverability indicators, or in other words:

- to increase the quantity of recovered components and materials,

- to increase the economic benefit (or to decrease the cost) of recovery,

- to increase the environmental benefit (or to decrease the environmental impact) of recovery.

Considering a given recovery scenario and a given recoverability criterion, the following procedure leading to the identification of relevant product attributes based on analysis of the recoverability assessment should be conducted by the design team:

- Setting up a prioritised list of so-called hot processes of the scenario, i.e. the recovery processes (for example, manual dismantling, sorting or recycling processes) that mostly influence recoverability of the product; the prioritisation is done after analysing and ranking the positive/negative impacts of the elementary processes that are expressed in the terms of the Eqs. (1)-(4).

- Setting up a prioritised list of so-called hot components/ parts, i.e. components/parts of the product (for example, a CRT or a structural plastic part) that are not adapted to the hot processes; the prioritisation is done after allocating the impact of the processes to the components/parts of the product according to an allocation rule per weight.

- Setting up a prioritised list of so-called hot attributes of the product, i.e. the attributes of the hot components/parts (for example, the weight of the part, the type of material or coating of a part) that are such that the components/parts are not adapted to the hot processes; the prioritisation is done after checking the attributes of the hot components/ parts against the performance of the hot processes.

The three-step procedure is schematised in Fig. 4.

From such a diagnosis, a design team is responsible for finding design alternatives to the hot attributes. These alternatives, also called improvement opportunities (IO), are to be suggested depending on the expertise of the members of the design team and the remaining solution space at the design stage.

\subsection{Selecting possible improvement opportunities in a multiscenario and multicriteria context}

It has been seen above how improvement opportunities according to a given scenario and a given criterion could be

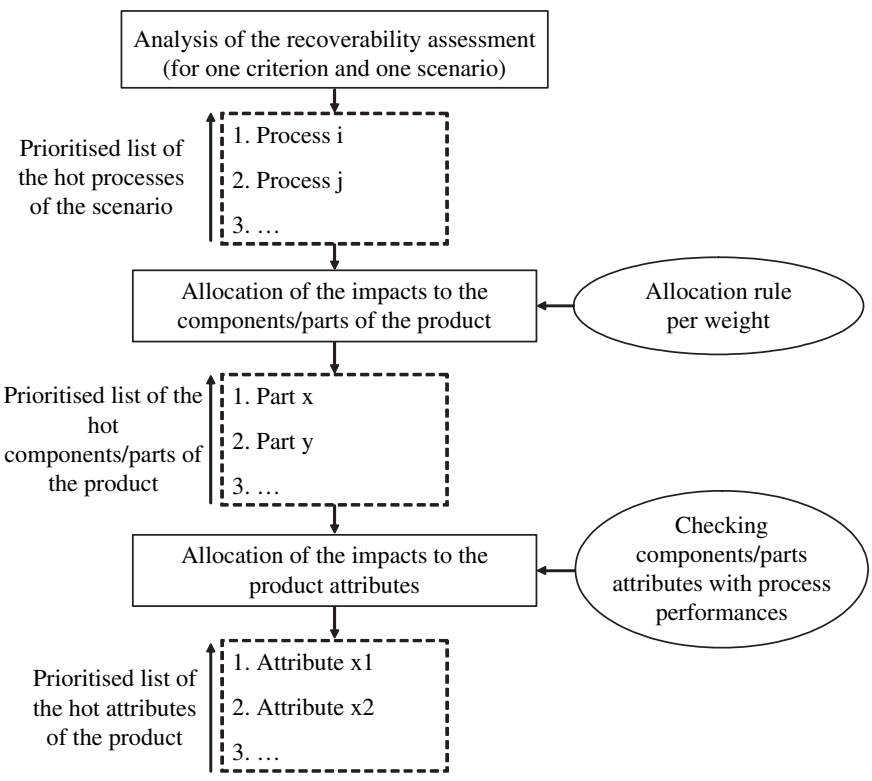

Fig. 4. The three-step procedure that leads to the identification of hot attributes on the basis of analysis of product recoverability assessment.

derived by designers from recoverability assessments. As represented in Fig. 5, for any given recoverability criterion, to any scenario bearing a letter from $\mathrm{A}$ to $\mathrm{Z}$ there corresponds a recovery assessment from $\mathrm{A}$ to $\mathrm{Z}$ and a list of improvement opportunities from A to Z. Similarly, for any given scenario, IOs can be obtained for each recoverability criterion.

In the ReSICLED framework, the management and prioritisation of the possible improvement opportunities should be led as follows.

We state that improvement opportunities according to several scenarios and/or several criteria can be described as common, antagonist and non-antagonist. This is illustrated in Table 4, where, considering two groups of IOs established by a design team, some common, antagonist and non-antagonist IOs are given for the choice of materials for some parts.

In such a context, compromises can be difficult to make and we suggest the two modes for the design team to manage improvement opportunities:

- either the so-called elitist mode, in which one group is preferred, for example group 1; the chosen IOs are those of group 1 associated with the non-antagonist IOs of group 2, as schematised in Fig. 6c,

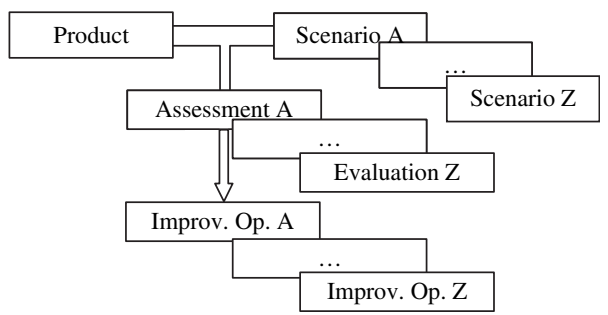

Fig. 5. Synoptic of a multiscenario recoverability assessment. 
Table 4

Examples of common, antagonist and non-antagonist improvement opportunities for two groups of IOs

\begin{tabular}{|c|c|c|}
\hline & Group 1 & Group 2 \\
\hline Common IOs & $\begin{array}{l}\text { Prefer the A material } \\
\text { for Part } n\end{array}$ & $\begin{array}{l}\text { Prefer the A material } \\
\text { for Part } n\end{array}$ \\
\hline Antagonist IOs & $\begin{array}{l}\text { Prefer the A material } \\
\text { for Part } n\end{array}$ & $\begin{array}{l}\text { Prefer the B material } \\
\text { for Part } n\end{array}$ \\
\hline Non-antagonist IOs & $\begin{array}{l}\text { Prefer the A material } \\
\text { for Part } n\end{array}$ & $\begin{array}{l}\text { Prefer the } B \text { material } \\
\text { for Part } m\end{array}$ \\
\hline
\end{tabular}

- or the so-called what-if mode, in which none of the groups are preferred; the chosen IOs are those of groups 1 and 2 that are not antagonistic to each other, as schematised in Fig. 6d.

Recovery aspects are never the only aspects taken into account by a design team when designing a product. Moreover, they rarely - if ever - are the priority ones [6]. In such a context, the choice among possible IOs is made by designers when handling compromises of several design criteria e.g. the cost, the quality and the recovery. At any design stage, a quantified assessment of possible recoverability benefits associated with a design change could be balanced against implications for other criteria. This compromise mode is not further explored here as it usually depends on the know-how of the design team.

\subsection{Co-operation in the design team}

Two types of main actors of the design teams have already been identified as possible actors of the method: the recycling expert and the designers. Their respective roles, as we foresee them, for the implementation of ReSICLED within a design project are clarified in Table 5 and in Fig. 7. It should be pointed out that any company willing to implement the ReSICLED

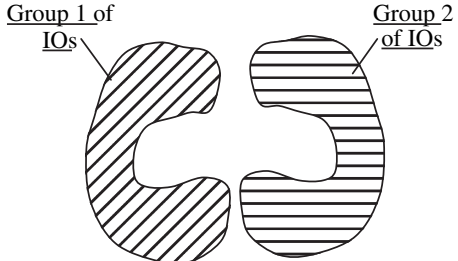

(a)

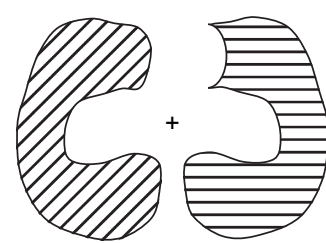

(c)

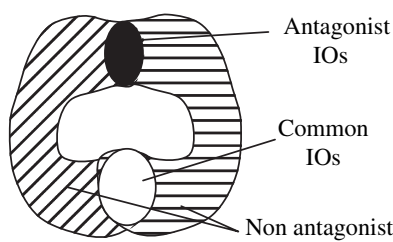

(b)

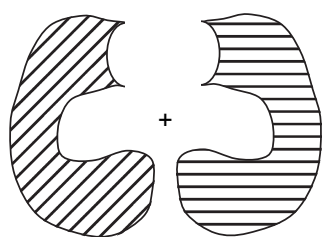

(d)
Fig. 6. Combining improvement opportunities: (a) two groups of IOs proposed by a design team; (b) common, antagonist and non-antagonist natures of the IOs of the two groups; (c) management of the IOs using the elitist mode, preferring group 1; and (d) management of the IOs using the what-if mode.
Table 5

Respective activities of a designer and of a recycling expert for the implementation of the ReSICLED method

\begin{tabular}{|c|c|c|}
\hline Actor & Designer & Recycling expert \\
\hline Activities & $\begin{array}{l}\text { Defines product design option } \\
\text { (usual design activity). } \\
\text { Calculates multicriteria and } \\
\text { multiscenario recoverability } \\
\text { indicators, considering scenarios } \\
\text { suggested by the recycling expert. } \\
\text { Analyses recoverability } \\
\text { indicators and, considering } \\
\text { choices made by the design } \\
\text { team concerning the prioritisation } \\
\text { of recoverability criteria, } \\
\text { identifies hot components/parts } \\
\text { and hot attributes. } \\
\text { Identifies possible } \\
\text { improvement opportunities. } \\
\text { Assesses the benefits } \\
\text { of possible improvement } \\
\text { opportunities and, considering } \\
\text { all relevant design } \\
\text { criteria and in accordance } \\
\text { with other members } \\
\text { of the design } \\
\text { team, decides } \\
\text { whether it should } \\
\text { be implemented. }\end{array}$ & $\begin{array}{l}\text { 1. Surveys recyclers, } \\
\text { collects data and updates } \\
\text { processes' database. } \\
\text { 2. Defines coherent } \\
\text { scenarios and defines } \\
\text { which ones should } \\
\text { be used for any given } \\
\text { design activity of the } \\
\text { design team. }\end{array}$ \\
\hline
\end{tabular}

method should not necessarily hire a recycling expert: this function could either be carried out by the company's environmental expert or by an external recycling expert who could intervene in the company on a regular basis.

\section{Case study: TV set}

\subsection{Product analysed and industrial context}

In this case study, the ReSICLED methodology is applied to a $14^{\prime \prime}$ TV put on the market in the year 2001 by one of our industrial partners. The product was initially dismantled in our laboratory and its composition regarding materials and architecture was established. Weights and the composition of the

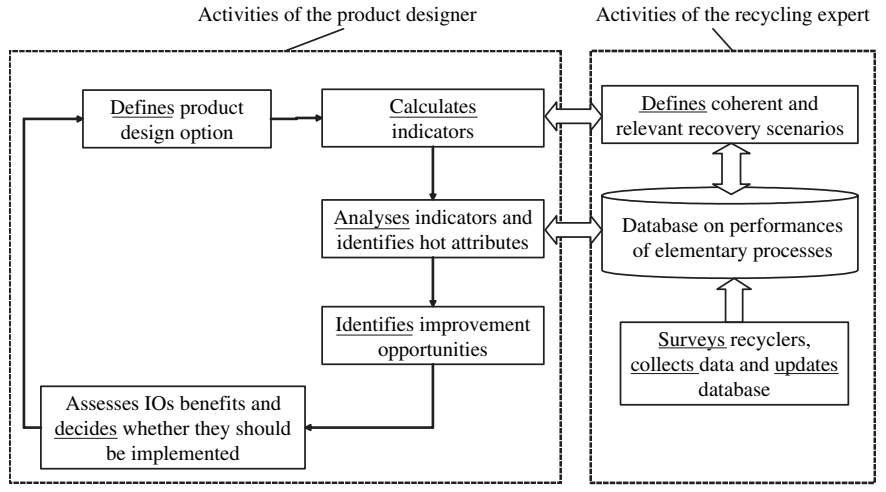

Fig. 7. Synoptic summarising the respective activities of a designer and of a recycling expert for the implementation of the ReSICLED method. 
materials of the constituent parts of the TV set are listed in column 3 of Table 6 .

This case study has been conducted in close cooperation with the product environmental manager of our industrial partner. Such work, disconnected from a real design team, is a simulation of the implementation of the ReSICLED method during a design project. For this simulation, the environmental manager was playing the role of a designer: this was indeed possible considering that this environmental manager was also a full member of some design teams, as polymer expert. We, researchers, well aware of EEE recovery routes, played the role of the recycling expert. The implementation of the ReSICLED method was simulated during the detailed design stage of the PDP, as defined in standards (e.g. Ref. [41]): at this stage, accurate data on the product's attributes is already defined and the remaining solution space is rather limited.

\subsection{Recovery scenarios considered}

After consultation of the recycling expert by the designer, it was decided that three recovery scenarios typical of the current European situation should be applied to the TV set, that they should be available today in Europe and that they should differ in the way they recover plastic materials. The recovery strategies of these scenarios are the recycling of materials and energy recovery. The strategy of re-using components is not considered in the case study.

For the three scenarios, the whole product is initially manually dismantled according to a procedure observed at an EEE

Table 6

Weight and composition of the materials of the constituent parts of the TV set - recovery routes for the constituent parts of the TV set according to three recovery scenarios

\begin{tabular}{|c|c|c|c|c|c|}
\hline \multirow[t]{2}{*}{ Parts } & \multirow{2}{*}{$\begin{array}{l}\text { Weight } \\
(\mathrm{g})\end{array}$} & \multirow[t]{2}{*}{ Composition of materials } & \multicolumn{3}{|c|}{ Recovery routes for the constituent parts of the TV set } \\
\hline & & & Scenario 1 (Europe) & Scenario 2 (Europe) & Scenario 3 (Europe) \\
\hline Cathode ray tube & 5165 & $\begin{array}{l}\text { Lead glass, } \\
\text { barium glass, luminescent } \\
\text { powder }\end{array}$ & $\begin{array}{l}\text { Manual separation of the } \\
\text { glass and recycling into } \\
\text { a new CRT }\end{array}$ & $\begin{array}{l}\text { Manual separation of the } \\
\text { glass and recycling into } \\
\text { a new CRT }\end{array}$ & $\begin{array}{l}\text { Manual separation of the } \\
\text { glass and recycling into a new } \\
\text { CRT }\end{array}$ \\
\hline $\begin{array}{l}\text { Printed board with } \\
\text { components (PWB) }\end{array}$ & 716 & $\begin{array}{l}\text { Precious metals, } \\
\text { copper, plastic }\end{array}$ & $\begin{array}{l}\text { Recycling of non-ferrous } \\
\text { metals and energy } \\
\text { recovery of plastics } \\
\text { in a smelting facility }\end{array}$ & $\begin{array}{l}\text { Recycling of non-ferrous } \\
\text { metals and energy } \\
\text { recovery of plastics } \\
\text { in a smelting facility }\end{array}$ & $\begin{array}{l}\text { Recycling of non-ferrous } \\
\text { metals and energy recovery } \\
\text { of plastics in a smelting } \\
\text { facility }\end{array}$ \\
\hline Electric cable & 102 & Copper, plastic & $\begin{array}{l}\text { Shredding, separation } \\
\text { of materials and recycling } \\
\text { of copper }\end{array}$ & $\begin{array}{l}\text { Shredding, separation } \\
\text { of materials and recycling } \\
\text { of copper }\end{array}$ & $\begin{array}{l}\text { Shredding, separation } \\
\text { of materials and recycling } \\
\text { of copper }\end{array}$ \\
\hline Cabinet & 583 & $\begin{array}{l}\text { High impact } \\
\text { polystyrene (HIPS) }\end{array}$ & Buried in controlled landfill & $\begin{array}{l}\text { Dismantling from TV set, } \\
\text { shredding with chassis-holder } \\
\text { and small parts, } \\
\text { gravimetric sorting and } \\
\text { recycling } \\
\text { of PP }\end{array}$ & $\begin{array}{l}\text { Advanced manual } \\
\text { dismantling and separation } \\
\text { from chassis-holders and } \\
\text { small parts, infrared } \\
\text { spectroscopy sorting and } \\
\text { recycling of PP }\end{array}$ \\
\hline Chassis-holder & 102 & $\begin{array}{l}\text { High impact } \\
\text { polystyrene + additive } \\
\text { (HIPS-Ad) }\end{array}$ & Buried in controlled landfill & $\begin{array}{l}\text { Dismantling from TV set, } \\
\text { shredding with cabinet } \\
\text { and small parts, } \\
\text { gravimetric sorting and } \\
\text { recycling } \\
\text { of PP }\end{array}$ & $\begin{array}{l}\text { Advanced manual } \\
\text { dismantling and separation } \\
\text { from cabinet and small } \\
\text { parts, infrared } \\
\text { spectroscopy sorting and } \\
\text { recycling } \\
\text { of HIPS }\end{array}$ \\
\hline
\end{tabular}


dismantling facility. Parts made of glass, precious metals, ferrous and non-ferrous metals are sent to recovery routes available today in Europe.

Only the routes for plastic parts differ for the three scenarios, as indicated in Table 6. Plastic parts are

- either buried in controlled landfill (Scenario 1),

- or shredded, with the particles sorted using gravimetric sorting technology and recycled (Scenario 2),

- or identified using infrared spectroscopy and recycled (Scenario 3).

The Scenarios 2 and 3 are typical of two different approaches to recycling materials:

- For Scenario 2, the purity of the materials after the sorting process is less important than the mechanical, thermal and economic properties of the recycled materials produced;

- For Scenario 3, the purity of the materials after the sorting process should be optimal - i.e. close to $100 \%$ - in order to produce recycled materials with properties equivalent to those of virgin materials.

According to the survey we undertook [44], each of these three recovery routes is currently used by at least two facilities in Europe.

\subsection{Data used for the calculation of recovery indicators}

Three kinds of data are used to calculate the recoverability indicators: functional, economic and environmental. Functional performance concerns the extent to which the purpose of a process, as defined in Table 2, is fulfilled. Most of the functional data concerning the recovery processes considered in the case study were extracted from ENSAM database. In particular, the recovery rates of some materials are established in Table 7 for the three scenarios. It should be pointed out that these recovery rates presented in Table 7 are aggregated values for the entire route: for example, the recovery rate for PP recycling in Scenario 2 aggregates losses for shredding, gravimetric sorting and recycling processes.
Data on the economic performance of processes are by definition difficult to obtain. Most of the data contained in ENSAM database were collected during exchanges with recyclers. Market values of plastic materials were found in an Internet-based Recyclers Exchange Index, e.g. [49]. Economic costs and benefits of the recovery routes of the Scenarios 1, 2 and 3 are established in Table 8 . Costs of some processes are presented in Table 9, after [44,50].

Two kinds of environmental data are needed for the calculation of the indicators:

- firstly, concerning the environmental impact associated with the production of materials and components contained in the products: this was collected in the database of the ecodesign software EIME,

- secondly, concerning the environmental impact of recovery processes.

However, for this case study, the data for the secondary inputs and outputs are not available for all recovery processes and environmental impacts of processes are not considered. Therefore, calculation of the EIRI $I_{I}$ only includes the environmental benefits of the production of recycled materials and recovered energy.

Here, the categories I of environmental impacts considered for the calculation of the environmental impact recoverability indicator $\left(\mathrm{EIRI}_{I}\right)$ are those adopted by the EIME software [51]. As it is difficult to take into account all environmental impact categories during the design of a product [52], the results of the $\mathrm{EIRI}_{I}$ are presented in this case study for a limited number of impact categories. Only environmental impact categories raw material depletion (RMD), global warming (GW) and water eutrophication (WE), which were previously identified as relevant for the case study [7], are presented.

Moreover, the environmental indicators are characterised on a relative basis when compared with a maximum value. As will be seen later, the EIRI $I_{I}$ are always environmental benefits in this case study. These values are then relatively characterised when compared with an optimal scenario, where the product/component is fully recovered without any environmental impact from the recovery processes. The notation of the EIRI $I_{I}$ characterised on a relative basis is $\left\|\operatorname{EIRI}_{I}\right\|$.

Table 7

Recovery rates of some materials in the recovery routes of the three scenarios

\begin{tabular}{|c|c|c|c|c|c|c|}
\hline \multirow[t]{2}{*}{ Materials } & \multicolumn{2}{|l|}{ Scenario 1} & \multicolumn{2}{|l|}{ Scenario 2} & \multicolumn{2}{|l|}{ Scenario 3} \\
\hline & $\begin{array}{l}\text { Recycling } \\
\text { rate }(\%)\end{array}$ & $\begin{array}{l}\text { Energy recovery } \\
\text { rate }(\%)\end{array}$ & $\begin{array}{l}\text { Recycling } \\
\text { rate }(\%)\end{array}$ & $\begin{array}{l}\text { Energy recovery } \\
\text { rate }(\%)\end{array}$ & $\begin{array}{l}\text { Recycling } \\
\text { rate }(\%)\end{array}$ & $\begin{array}{l}\text { Energy recovery } \\
\text { rate }(\%)\end{array}$ \\
\hline Glass from the CRT & 95 & 0 & 95 & 0 & 95 & 0 \\
\hline $\begin{array}{l}\text { Non-ferrous metals in the } \\
\text { printed boards }\end{array}$ & 95 & 0 & 95 & 0 & 95 & 0 \\
\hline Plastics from the printed boards & 0 & 95 & 0 & 95 & 0 & 95 \\
\hline Ferrous and non-ferrous metals & 95 & 0 & 95 & 0 & 95 & 0 \\
\hline $\mathrm{PP}$ & 0 & 0 & 80 & 0 & 97 & 0 \\
\hline HIPS & 0 & 0 & 0 & 0 & 97 & 0 \\
\hline
\end{tabular}


Table 8

Economic costs and benefits of several recovery routes of the three scenarios

\begin{tabular}{llc}
\hline Scenarios & Recovery routes & $\begin{array}{c}\text { Costs }(<0) \text { and benefits } \\
(>0)(€ / \mathrm{kg} \text { of input })\end{array}$ \\
\hline Scenarios 1, 2 and 3 & Recycling of ferrous metals & 0.004 \\
& Recycling of printed boards & 0.076 \\
& CRT recovery & -0.23 \\
& Recycling of Cu-dominated & 0.25 \\
& mixes & \\
Scenarios 2 and 3 & Landfilling & -0.12 \\
Scenario 3 & Recycling of sorted PP & 0.23 \\
\hline
\end{tabular}

Sources: Refs. [44,49].

\subsection{Results and analysis of the recoverability assessment}

The results of the recoverability indicators for the original design of the TV set, as they could be calculated by a product designer, are presented for the three indicators on the lines "Original Design" in Table 10. For the weight criteria, only the $\mathrm{WRI}_{\text {Recovery }}$ is computed.

In these results, the recoverability of a product appears highly dependent upon the scenario and the criterion that are considered. In particular:

- The weight recovery rates are higher than the legal limit of $75 \%$ - required for a TV set by the European Parliament [2] - for only two of the three scenarios.

- The recovery cost fluctuates widely: it is around $€ 2.20 / T V$ set for Scenarios 1 and 2 and it reaches $€ 3.50 / \mathrm{TV}$ set for Scenario 3.

- The environmental criteria also vary: EIRI are indeed strongly related to the WRI for the impact on GW and WE when RMD does not vary much.

The quantitative assessment of the product's recoverability seems to be appreciated by our industrial partner: after consultation of the results, he acknowledges that recoverability assessments can be very useful to a design team, as recoverability could be effectively discussed against other design criteria, e.g. production costs.

As described in Section 5.1, the design team is now able to establish the impact of each process on the recoverability of the product on the basis of the quantified indicators. The impact of a process on the product's recoverability is

- either a recoverability loss for the weight and environmental criteria,

- or a recoverability loss or gain for the economic criterion.

Table 9

Cost of some of the recovery processes of the three scenarios

\begin{tabular}{lll}
\hline Scenarios & Recovery processes & Cost \\
\hline Scenarios 1, 2 and 3 & $\begin{array}{l}\text { Manual dismantling } \\
\text { Shredding and gravimetric }\end{array}$ & $€ 13 / \mathrm{h}$ \\
Scenario 2 & $\begin{array}{l}\text { sorting } \\
\text { Scenarios 3 }\end{array}$ & \\
\hline
\end{tabular}

Sources: Refs. [44,50].
The impact of some of the processes of Scenario 2 on recoverability of the TV set is shown in Figs. 8 and 9. As can be seen in these figures, the recovery processes influence the three recoverability criteria in different ways. After analysing and ranking their positive/negative impacts, designers can establish prioritised lists of hot processes. These lists are presented in Table 11 for each criterion for the recovery of the TV set according to Scenario 2.

According to the second step of the procedure, impacts of the processes are allocated to the product parts/components on a weight basis: for example, for the weight criterion, the loss of the "Sorting particles from cabinet + chassis-holder + small parts" process is allocated per weight to the main parts fed as input to the process, firstly the cabinet, secondly the chassis-holder, thirdly the small parts. Considering the value of the loss attributed to each component, some prioritised lists of hot components/parts are established, as shown in Table 12 below for each criterion for the recovery of the TV set according to Scenario 2.

The performance of each hot process, defined for a few processes in Table 3, is now analysed by the designers and checked against the attributes of the hot components/parts. This leads to prioritised lists of the product's hot attributes being drawn up, as established in Table 13 below for each criterion and for Scenario 2. For example, for the weight criterion, the mass of waste generated by the "Sorting particles using gravimetric sorting" process is linked to the type of plastic and to the weight of the input, as depicted in column 6 of Table 3. The hot components/parts "cabinet" and "chassisholder" are not adapted to the process are they are not made of PP and their attribute "type of material" is identified as a product's hot attribute.

\subsection{Improving the design of the product}

Through the analysis, the design team is able to draw up, for each criterion, the product's hot attributes that mostly influence the product's recoverability. On the basis of this list, as stated in Section 5.1, the designers should now be able to suggest design improvement opportunities.

The assessment results given earlier have been presented and discussed with our partner. It was decided with him that design improvement opportunities for the product should be identified when adopting an "elitist" management of the scenarios as he wishes to optimise the product's design considering only one most probable scenario. It was also decided that Scenario 2 (shredding) should be considered as the most likely to be applied to the product's end-of-life because:

- the recovery cost is the lowest for the scenarios that exceed the legal requirements for the WRI,

- this technology is already used by several recycling facilities in Europe; it can also treat other types of waste streams, for example automotive shredder residues; the availability of this technology at the end-of-life of the TV set is therefore highly probable. 
Table 10

Case study 2: results of the multicriteria recoverability assessment for a TV set - recovery scenarios currently available in Europe

\begin{tabular}{|c|c|c|c|c|c|c|}
\hline \multirow[t]{3}{*}{ Design } & \multirow[t]{3}{*}{ Scenarios } & \multicolumn{5}{|c|}{ Multicriteria recoverability indicators } \\
\hline & & \multirow{2}{*}{$\begin{array}{l}\text { WRI }_{\text {Recycling (\% weight }} \\
\text { of the product) }\end{array}$} & \multirow[t]{2}{*}{ ERI (€/product) } & \multicolumn{3}{|c|}{$\|$ EIRI $\|$ ( $\%$ of maximum benefit $)$} \\
\hline & & & & RMD & GW & WE \\
\hline \multirow[t]{3}{*}{ Original design } & Scenario 1 & 67 & -2.20 & 94 & 57 & 40 \\
\hline & Scenario 2 & 75 & -2.23 & 94 & 66 & 42 \\
\hline & Scenario 3 & 84 & -3.55 & 94 & 78 & 44 \\
\hline \multirow[t]{3}{*}{ Re-design } & Scenario 1 & 67 & -2.20 & 94 & 59 & 40 \\
\hline & Scenario 2 & 80 & -2.06 & 94 & 75 & 43 \\
\hline & Scenario 3 & 84 & -3.59 & 94 & 80 & 44 \\
\hline \multirow[t]{4}{*}{ Difference } & Scenario 1 & 0 & 0 & 0 & +3 & 0 \\
\hline & Scenario 2 & +6.5 & +7.6 & 0 & +13 & +2 \\
\hline & Scenario 3 & 0 & -1.1 & 0 & +2 & 0 \\
\hline & Scenario $1+2+3$ & +2.2 & +1.6 & 0 & +4 & +1 \\
\hline
\end{tabular}

Therefore, considering Scenario 2, hot processes, hot components/parts and hot attributes identified by us after the analysis of the recoverability assessment, have been presented and discussed with our partner. He was able, in cooperation with us, to identify some IOs. A few of them are listed in Table 14. Most of them concern the types of CRT, the type of PWB, the type of assembly technology and the type of materials for the plastic parts. The ability of each IO to be implemented at the detailed design stage of the TV set is also established. At this stage of the design, only the improvement opportunity $\mathrm{IO}_{5}$ can be implemented.

In accordance with the industrial partner, implementation of the $\mathrm{IO}_{5}$ is simulated and $\mathrm{PP}$ is the material chosen for re-design of the cabinet. As discussed with our industrial partner, such a design modification is technically possible so long as it is made early enough to cope with manufacturing requirements.

The multicriteria recoverability assessments of the redesigned product are presented for the three scenarios in Table 10 in the lines "Re-Design". Differences between the original design and the Re-design are also listed in the lines "Difference" of the same Table 10.

As we expected, implementing the improvement opportunity $\mathrm{IO}_{5}$ is beneficial or neutral for all criteria for Scenario 2. It is also beneficial for the two other scenarios and for the three criteria, except for the ERI of Scenario 3 for which it

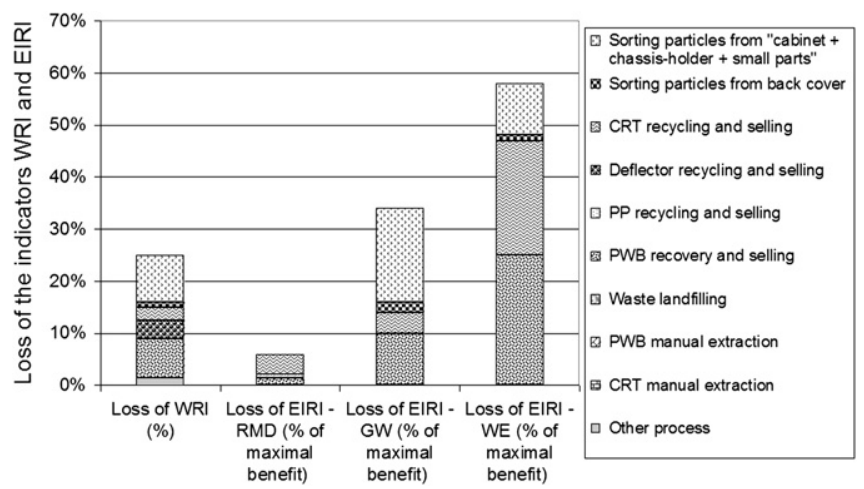

Fig. 8. Negative impact of several processes of Scenario 2 on the recoverability of the TV set for the weight and environmental criteria. is detrimental. This can be explained by the lower market value of recycled PP compared to recycled HIPS. Moreover, if the flow of end-of-life TV sets is shared equally among all three scenarios (cf. line "Scenarios $1+2+3$ "), the implementation of $\mathrm{IO}_{5}$ is beneficial or neutral for all criteria.

The economic benefit reaches $+7.6 \%$ for Scenario 2 and $+1.6 \%$ for a mix of the three scenarios. These values could represent a huge amount of money when considering the total number of TV sets that reach the end of their lives every year on the European continent. Obviously, in the industrial context, these economic benefits should be balanced with economic costs or benefits that the re-design option would imply at other life cycle stages, in particular at the raw materials purchasing and the production stages.

Concerning the environmental indicator EIRI, the re-design is beneficial for the categories GW and WE. The RMD indicator does not vary much as it is very much correlated to the material contents of the CRT, the deflector and the printed board (cf. [51]) that are not modified by the re-design.

\subsection{Conclusions from case study}

Through this case study, it was shown that the recoverability of a product is highly dependent upon the scenario which is considered. This shows that the concept of recoverability of

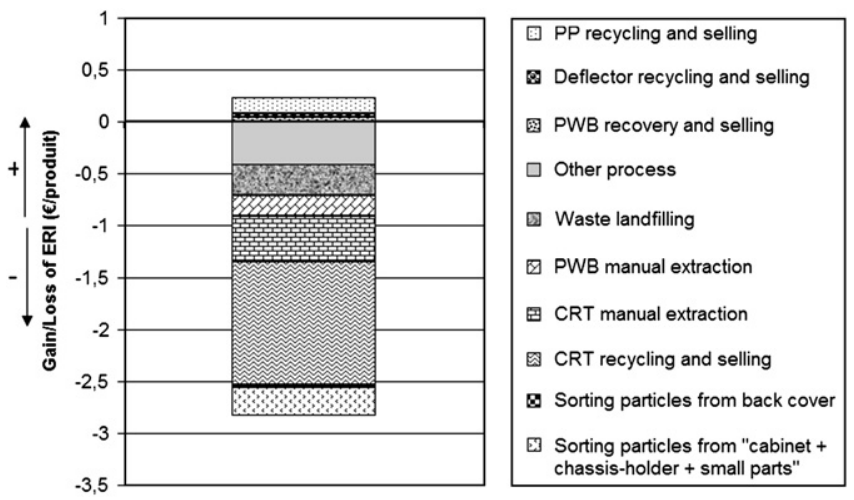

Fig. 9. Positive and negative impact of several processes of Scenario 2 on the recoverability of the TV set for the economic criterion. 
Table 11

Prioritised lists of hot processes for each criterion for the recovery of the TV set according to Scenario 2

\begin{tabular}{|c|c|c|c|c|c|}
\hline \multirow{2}{*}{$\begin{array}{l}\text { Weight criterion } \\
\text { (negative impact) }\end{array}$} & \multicolumn{2}{|l|}{ Economic criterion } & \multicolumn{3}{|c|}{ Environmental criterion (negative impact) } \\
\hline & Positive impact & Negative impact & RMD & GW & WE \\
\hline $\begin{array}{l}\text { 1. Sorting particles } \\
\text { from "cabinet }+ \text { chassis- } \\
\text { holder }+ \text { small parts" } \\
\text { 2. PWB recycling and selling } \\
\text { 3. Deflector recycling } \\
\text { and selling } \\
\text { 4. CRT recycling and selling }\end{array}$ & $\begin{array}{l}\text { 1. PP recycling } \\
\text { and selling } \\
\text { 2. PWB recycling } \\
\text { and selling } \\
\text { 3. Deflector recycling } \\
\text { and selling }\end{array}$ & $\begin{array}{l}\text { 1. CRT recycling and selling } \\
\text { 2. CRT manual extraction } \\
\text { 3. Waste landfilling } \\
\text { 4. Sorting particles } \\
\text { from "cabinet + chassis- } \\
\text { holder + small parts" }\end{array}$ & $\begin{array}{l}\text { 1. CRT recycling } \\
\text { and selling } \\
\text { 2. Deflector recycling } \\
\text { and selling } \\
\text { 3. PWB recycling } \\
\text { and selling }\end{array}$ & $\begin{array}{l}\text { 1. Plastic sorting } \\
\text { 2. PWB recycling } \\
\text { and selling } \\
\text { 3. CRT recycling } \\
\text { and selling }\end{array}$ & $\begin{array}{l}\text { 1. PWB recycling and selling } \\
\text { 2. CRT recycling and selling } \\
\text { 3. Sorting particles } \\
\text { from "cabinet + chassis- } \\
\text { holder + small parts" }\end{array}$ \\
\hline
\end{tabular}

a product can only be discussed when the scenarios applied are carefully defined. The calculations also emphasise the necessity of adopting a multicriteria approach for the recoverability: considering a scenario (e.g. Scenario 3 ), the recoverability of a product can be satisfactory according to one criteria (e.g. the weight criterion) and hardly acceptable for another criteria (e.g. the economic criterion). The ReSICLED framework indeed allows designers to consider the multicriteria characteristics of the recoverability within a multiscenario context.

It was shown through exchanges with industries that assessing the recoverability of a product or a component on a quantitative basis seems to make it more tangible for designers.

Thanks to multiprocess modelling, it has also been demonstrated how many components and attributes of a product diversely influence its overall product recoverability.

It was also shown how the analysis of the multicriteria recoverability assessments can lead to the identification of improvement opportunities that could imply some appreciable recoverability gains, if implemented. In the multiscenario context, before implementing any improvement opportunities, designers have to make sure that the gains obtained with one possible scenario are not counteracted by losses with others.

\section{Discussion on ReSICLED's benefits and drawbacks and on its development perspectives}

\subsection{Satisfies a need}

The ReSICLED method was developed to satisfy the need formulated in Section 2.5. It was shown during the application to a product that this new RCD method:
- can produce quantitative assessment of a product's recoverability according to criteria that seem relevant to producers and therefore makes the recoverability more tangible to designers;

- is able to take into account performances, requirements and reality of many recovery processes that contribute to the product's recovery;

- allows a design team to consider the multiplicity of recovery scenarios that can be applied to a product at its end-oflife at a specific place and time;

- can be used by a design team to identify relevant hot parts and hot attributes of a product, and to suggest relevant improvement opportunities;

- allows design teams to assess the possible benefits associated to the possible improvement opportunities.

Table 15 summarises the characteristics of the ReSICLED method using the same analysis grid as the one used in Table 1.

\subsection{Identifies a wide range of attributes affecting the recoverability}

The ReSICLED method has been applied so far to a limited number of products and components, such as a TV set, presented in this paper, printed boards of several generations of mobile phones and some plastics parts of another TV set presented elsewhere $[7,53,54]$. The case study presented in this paper led to the identification of a limited number of improvement opportunities that only concerned the CRT's accessibility and type, the PWB's type and the type of plastic for some parts. The other case studies considered a greater number of more elaborated recovery processes and led to a list of more

Table 12

Prioritised list of hot components/parts for each criterion for the recovery of the TV set according to Scenario 2

\begin{tabular}{|c|c|c|c|c|c|}
\hline \multirow{2}{*}{$\begin{array}{l}\text { Weight criterion } \\
\text { (negative impact) }\end{array}$} & \multicolumn{2}{|c|}{ Economic criterion } & \multicolumn{3}{|c|}{ Environmental criterion (negative impact) } \\
\hline & Positive impact & Negative impact & RMD & GW & WE \\
\hline 1. Cabinet & 1. Back cover & 1. CRT & 1. CRT & 1. Cabinet & 1. PWB \\
\hline 2. Chassis-holder & 2. PWB & 2. Cabinet & 2. Deflector & 2. PWB & 2. CRT \\
\hline 3. PWB & 3. Deflector & 3. Chassis-holder & 3. PWB & 3. CRT & 3. Cabinet \\
\hline 4. Deflector & & & & 4. Chassis-holder & 4. Chassis-holder \\
\hline 5. CRT & & & & 5. Back cover & 5. Back cover \\
\hline 6. Back cover & & & & & \\
\hline
\end{tabular}




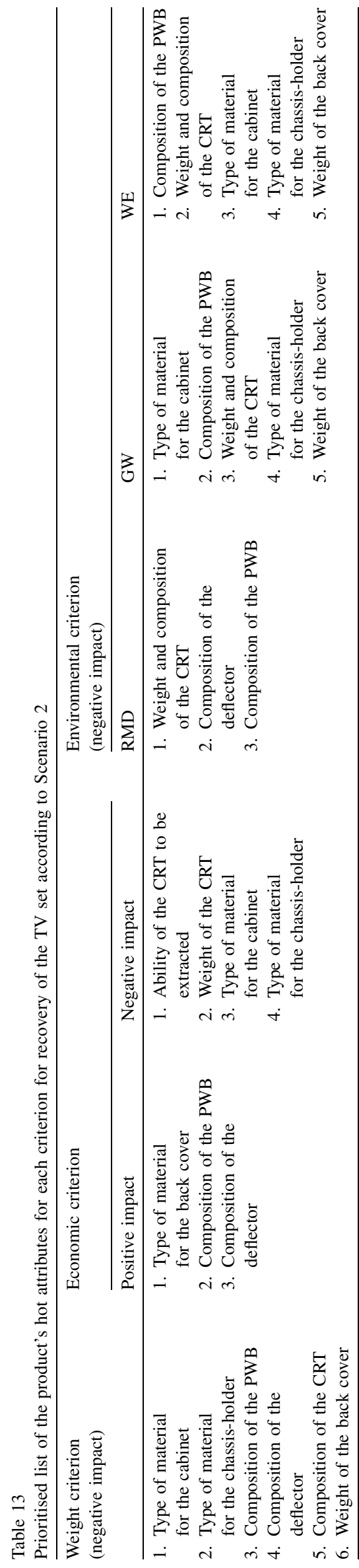

abundant and diverse improvement opportunities. They also provided the opportunity to identify the attributes that influence a product's recoverability in the ReSICLED model. All relevant product attributes that were identified for the case studies are listed and organised below in three groups of relevant attributes:

- attributes concerning the material: material type, material density, material wettability, material tensile strength at yield, calorific content of material, economic value of recycled material, economic value of virgin material, market saturation rate, environmental content of the material, composition of material in substances, material of a dangerous nature, and material of a polluting nature,

- attributes concerning the fastening between parts: fastening type, number of fastenings,

- attributes of the architecture of the parts and product: weight of the part, colour of the part, longest dimension of the part, type of labelling on the part, type of coating on the part, and fastening of the part with other parts.

This shows that for any product and for any recovery scenario, the ReSICLED method makes it possible to identify many more relevant and accurate product attributes than the ones usually considered in RCD methods, e.g. type of materials, type and numbers of fastenings and dismantling precedence issues. Thanks to the recoverability assessment, a design team is also able to establish not only which attributes influence the product's recoverability but above all to what extent. This allows all members of a design team to influence product recoverability through their choices.

\subsection{A method still to be completed}

Through the ReSICLED method, a general framework for better integration of end-of-life recovery aspects at the design stage of a product has been developed. However, some aspects of the framework are still unsatisfactory and need to be further researched so that the method can be efficiently deployed in industry. In priority, it will be necessary:

- to transform the method into a software tool: presently, the method implies much time-consuming paper and spreadsheet work and is more a method for researchers than for designers; transforming the method into a software tool could make its systematic use possible during real design projects; we believe that a software tool should in particular allow the designer's activities numbered 2 (calculation of recovery indicators) and 3 (identification of hot processes, components and attributes) in Table 5 to be automated from a product's CAD modelling; this is currently being explored;

- to integrate additional modelling of recovery processes, e.g. concerning the product and component re-use strategy;

- to integrate some theoretical process modelling, e.g. as proposed for shredding processes $[28,55,56]$ and sorting 
Table 14

List of opportunities for improving the recoverability of the TV set according to Scenario 2

\begin{tabular}{|c|c|c|c|}
\hline Hot process/recoverability criteria & Hot attribute & Improvement opportunities & $\begin{array}{l}\text { Status of the rules at the detailed } \\
\text { design stage of the TV set }\end{array}$ \\
\hline Manual product dismantling/€ & Ability of the CRT to be extracted & $\begin{array}{l}\mathrm{IO}_{1}: \text { "Reduce the number of } \\
\text { fastenings to extract CRT" }\end{array}$ & Already optimised \\
\hline Manual product dismantling/€ & Ability of the CRT to be extracted & $\begin{array}{l}\mathrm{IO}_{2}: \text { "Choose easy to dismantle fastening } \\
\text { types to extract CRT" }\end{array}$ & Already optimised \\
\hline CRT recycling/€, RMD, GW & Weight of the CRT & $\mathrm{IO}_{3}:$ "Choose a lighter $C R T "$ & Non-modifiable \\
\hline $\mathrm{PWB}$ recycling/\%, $€, \mathrm{RMD}, \mathrm{GW}$ & $\begin{array}{l}\text { Composition of the PWB: too much } \\
\text { non-recoverable material }\end{array}$ & $\begin{array}{l}\mathrm{IO}_{4}: \text { "Decrease the amount of non-recoverable } \\
\text { materials in } P W B "\end{array}$ & Non-modifiable \\
\hline Plastic sorting/\%, $€, \mathrm{GW}$ & $\begin{array}{l}\text { Type of material for the cabinet } \\
\text { and the chassis-holder }\end{array}$ & $\mathrm{IO}_{5}:$ "Use PP for cabinet and chassis-holder" & Modifiable \\
\hline
\end{tabular}

processes $[48,57,58]$; such a modelling could be based on a statistical framework, as recommended in Ref. [8]; this should lead to better and more accurate understanding of recovery route performance;

- to suggest an evaluation method of recovery route availability at a certain time and place to be used by the recycling expert when selecting scenarios;

- to validate and expand, through empirical measurement, the database that includes the performances of recovery processes;

- to incorporate models that take into account the fluctuations in the prices of virgin and recycled materials;

- to suggest a model for the quantification of uncertainties in the recoverability assessment: this should help decisionmaking when choosing among a list of possible improvement opportunities.

Table 15

Qualitative analysis of the new ReSICLED method

\begin{tabular}{|c|c|}
\hline Analysis criteria & ReSICLED \\
\hline $\begin{array}{l}\text { Recovery processes and } \\
\text { systems considered (RCD group) }\end{array}$ & $\begin{array}{l}\text { Eight types of elementary recovery } \\
\text { processes: dismantling, shredding, } \\
\text { sorting, recycling, incineration, selling } \\
\text { recycled materials, landfilling, } \\
\text { and logistics (RSCD) }\end{array}$ \\
\hline \multicolumn{2}{|c|}{ Ability to integrate uncertainties of recovery routes } \\
\hline Geographic & $\begin{array}{l}V^{a}(\text { explicitly through } \\
\text { multiscenario approach })\end{array}$ \\
\hline Temporal & $\begin{array}{l}(\mathscr{\sim})^{\mathrm{b}} \text { (explicitly through multiscenario } \\
\text { approach - possibility to consider } \\
\text { prospective scenarios is not } \\
\text { demonstrated here) }\end{array}$ \\
\hline \multicolumn{2}{|l|}{ Recoverability criteria considered } \\
\hline Per weight & レ \\
\hline Economic & レ \\
\hline Environmental & レ \\
\hline \multicolumn{2}{|c|}{ Ability to be used during the product development process } \\
\hline Product attributes & $\begin{array}{l}\text { Many, organised according to } \\
\text { three groups: material/fastening/ } \\
\text { architecture }\end{array}$ \\
\hline $\begin{array}{l}\text { Integration into the } \\
\text { design process }\end{array}$ & $\begin{array}{l}(\boldsymbol{\sim}) \text { (only validated during the } \\
\text { detailed design stage of the PDP) }\end{array}$ \\
\hline
\end{tabular}

\footnotetext{
${ }^{\text {a }}$ Widely integrated.

${ }^{\mathrm{b}}$ Partially integrated.
}

\subsection{A method that should be better articulated with the product development process}

The ReSICLED method has so far been applied to a limited number of case studies, always simulating the re-design of existing products during the detailed design phase of the PDP. Further case studies and implementation of the method during real design projects will be needed so that:

- the use and benefits of the ReSICLED method for the design of other components than plastic parts are tested;

- the applicability, reliability and benefits of the method are tested at earlier stages of the PDP, in particular at the conceptual design phase: at this stage, data concerning the product are still incomplete but the degree of freedom is larger for designers;

- the usefulness of the method is tested for several types of products with various degrees of complexity, e.g. containing various numbers of materials;

- the procedures and limitations of applying prospective scenarios to products within the ReSICLED framework can be explored; benefits associated with prospective scenarios, in particular in terms of increased design space for designers, should moreover be studied;

- the roles of designers and of recycling experts within the ReSICLED framework are further examined: this will allow further discussion of the combination of responsibilities between designers and the recovery expert within a company, as discussed in Table 5. Problems will probably arise as the future users of the method, i.e. designers, are not recovery specialists. However, designers' creativity and their ability to find original design improvement opportunities will hopefully overcome any implementation problems.

\section{Conclusions}

Complex product manufacturers should improve the design of their products more and more in relation to their end-of-life treatment. Manufacturers have therefore to ensure the appropriateness of the products to the recovery processes. Recovery activity is usually made of a system of processes. Moreover, it 
varies strongly among regions and countries and is quickly evolving. Not only currently available recovery technologies but also promising ones for the future should therefore be considered by manufacturers when designing products. Temporal but not geographical variability are currently considered in some previous RCD methods. In a few cases, the prospective aspects are integrated in an aggregated form, especially in databases. The identified approaches seem, however, little transparent. The existing RCD methods are also poorly linked to the product development process.

Our literature review resulted in the formulation of the need to develop better devised RCD methods. On this basis, a new RCD method called ReSICLED has been developed. It consists of using the results of multicriteria and multiscenario recoverability assessments during the product development process. The original modelling that makes the calculation possible and procedures leading to the calculation have also been expressed. We demonstrated, through a case study, how the new method could be implemented in practice and what the benefits of using it could be. The main originality of the method, i.e. the quantitative, multicriteria, multiscenario and multiprocess characteristics, has been underlined. Finally, the benefits and drawbacks and the method's further developments have been discussed.

\section{Acknowledgements}

This research has been funded by the Région Rhônes-Alpes regional government and by the French Environmental Protection Agency, Ademe. The authors are grateful to the electronic equipment manufacturers Alcatel, Schneider Electric and Thomson whose cooperation made possible the definition of a method that aims at answering designers' questions. This research could not has been led without the cooperation of many recyclers in particular Valdelec, EEE recycler (Chambéry, France), Technopolymer, plastic material recycler (Nagoya, Japan) and RPI, plastic material recycler (Salt Lake City, USA). Life cycle data extracted from the EIME software database were used for the EIRI calculations. Authors would also like to thank P. Ciszewska and H. Lanter for the grammatical review of this paper.

\section{References}

[1] CEC. Recycling forum - Final report. Brussels (Belgium); 2000.

[2] CEC. Directive of the european parliament and of the council on the waste electric and electronic equipment. 2002/96/CE. Brussels (Belgium); 2002

[3] CEC. Decision of the Commission establishing the ecological criteria for the attribution of Community ecolabel for TV sets. Brussels (Belgium); 2002.

[4] Rose CM. Design for environment: a method for formulating product end-of-life strategies. PhD thesis, Stanford University; 2000.

[5] Coppens C. A design method that aims at improving the recovery of endof-life automotive vehicles. PhD thesis, Ecole Nationale Supérieure des Arts et Métiers de Paris; 1999 [in French].

[6] Gaucheron T. Integrating recycling in product design. The product model: a descriptive and cognitive tool that helps to take recycling into account. PhD thesis, Institut National Polytechnique de Grenoble; 2000 [in French].

[7] Mathieux F. Towards better integration of the end-of-life recovery aspects at the design stage of a product - a method based on the multicriteria assessment of the product's recyclability and on the identification of weak points of its design. PhD thesis, Ecole Nationale Supérieure des Arts et Métiers de Chambéry; 2002 [in French].

[8] van Schaik A, Reuter MA, Heiskanen K. The infuence of particle size reduction and liberation on the recycling rate of end-of-life vehicles. Minerals Engineering 2004;17(2):331-47.

[9] Eckerth G. State-of-the-art of collection logistics. In: Proceedings of public ecolife workshop. Chambéry, France: ENSAM Chambéry; 21 January 2002.

[10] Nagel C, Nilsson J, Boks C. European end-of-life systems for electrical and electronic equipment. In: Proceedings of first international symposium on environmentally conscious design and inverse manufacturing. Tokyo (Japan); 1999.

[11] Imai T. Sorting of plastics from WEEE - new recycle process for plastics recovered from wasted E\&E equipment. In: Proceedings of identiplast 2001. Brussels (Belgium); 2001.

[12] Kobler RW, Winslow G, Bedell CJ, Christopher P. A pre-production pilot plant for processing of automotive shredder residues. In: Proceedings of eighth annual global plastics environmental conference (GPEC), 13-14 February 2002, Detroit (USA)

[13] Krummenacher B, Peuch P, Fisher M, Biddle M. Automatic identification and sorting plastics from different waste streams. Technical report: APME - identiplast; 1998.

[14] VDI. VDI 2243-Konstruieren recyclinggerechter technischer Produkte. Verein Deutscher Ingenieure. Berlin (Germany): Beuth Verlag GmbH; 1993.

[15] Navin-Chandra D. ReStar: a design tool for environmental recovery analysis. In: Proceedings of international conference on engineering design, 17-19 May 1993. The Hague, The Netherlands; 2003.

[16] Dowie TA. A disassembly planning and optimisation methodology for design. PhD thesis, Manchester Metropolitan University; 1995.

[17] Simon M, Mc Laren J, Dowie T. Feasibility of a common indexing system for recycling of electronic products. Technical report, Manchester (United Kingdom): Manchester Metropolitan University; 1996.

[18] ICER. Design for recycling electronic and electronic equipment. Technical report, Londres (United Kingdom): Industry Council for Electronic equipment Recycling (UK); 1997.

[19] Lee BH, Ishii K. The recyclability map: application of demanufacturing complexity metrics to design for recyclability. Journal of Sustainable Product Design 1998;5:38-48.

[20] Knight W, Curtis M. Design for environment software development. Journal of Sustainable Product Design 1999;9:36-44.

[21] Feldmann K, Meedt O, Trautner S, Scheller H, Hoffman W. The green design advisor: a tool for design for environment. Journal of Electronics Manufacturing 1999;9(1):17-28.

[22] Ferrendier S, Mathieux F, Rebitzer G, Simon M, Froelich D. Environmentally improved product design - case studies of the European electric and electronic industry. Available from: <http://www.ihrt.tuwien.ac.at/sat/ base/ecolife/index.html $>$; 2002 [accessed 20.02.04].

[23] Kang HY, Jung JW, Herrmann C. Recycling oriented design - a case study on house appliances using the software ATROiD. In: Proceedings of ecodesign 2001 - Second International symposium on environmentally conscious design and inverse manufacturing. Tokyo (Japan): IEEE; 2001.

[24] Knight WA, Sodhi M. Design for bulk recycling: analysis of materials separation. CIRP annals 2000;49:83-6.

[25] AFNOR. Automotive vehicles - design of the vehicles that aim at the optimisation of their end-of-life recovery. Paris (France): Association Française de Normalisation; 1996. XP R10-402 [in French].

[26] Hundal M. Design for recycling and remanufacturing. In: Proceedings of International design conference - design 2000, 23-26 May 2000. Dubrovnik (Croatia).

[27] Renard H. Improving the recyclability of multimaterial automotive equipment. Ingénieurs de l'Automobile; November-December 2001: 133-136 [in French]. 
[28] Castro MB, Remmerswaal JAM, Brezet JC, van Schaik A, Reuter MA. A simulation model of the comminution-liberation of recycling streams relationships between product design and the liberation of materials during recycling. International Journal of Minerals Processing 2005;75(3-4):255-81.

[29] Furuhjelm J. Incorporating the end-of-life aspect into product development. $\mathrm{PhD}$ thesis, Linköpings University; 2000.

[30] Cobra-Flores E, Bustani A, Mackay PW, Ramirez S, Sullivan JL, Williams R. An analysis of the vehicle end-of-life in the US. Society of Automotive Engineers; 1998. SAE 982213.

[31] ISO. Road vehicles - recyclability and recoverability - calculation method. International Organization for Standardization; 2002. ISO 22628.

[32] Fleischer G, Becker J, Braunmiller U, Klocke F, Klöpffer W, Michaeli W. Eco-design - Effiziente Entwicklung nachhaltiger Produkte mit euroMat. Berlin (Germany): Springer Verlag, ISBN 3-540-65814-9; 2000.

[33] Huisman J, Boks C, Stevels A. Quotes for environmentally weighted recyclability - the concept of describing product recyclability in terms of environmental value. International Journal of Production Research 2003; 41(16):3649-65.

[34] Herrmann C, Eyerer P, Gediga J. Economic and ecological material index for end of life and design of electronic products. In: Proceedings of international symposium on electronics and the environment. San Francisco (USA); 2002.

[35] Korse-Noordhoek M, Boks C, Stevels A. Pros and cons of adjusting and extending functionality of first generation end-of-life evaluation tools in relation to user requirements. In: Proceedings of ecodesign $2001-\mathrm{sec}-$ ond international symposium on environmentally counscious design and inverse manufacturing. Tokyo (Japan): IEEE; 11-15 December 2001.

[36] CEC. Environment 2010: our future, our choice. Sixth community action program on the environment. Brussels (Belgium); 2001.

[37] Ebach H. Recycling analysis and design software: demrop, Activity report of the Brite-Euram program. München (Germany): Siemens AG; 1997.

[38] Janin M. Ecodesign approach in company - a stake: building a coherence between tools and design process. PhD thesis, Ecole Nationale Supérieure des Arts et Métiers de Chambéry; 2000 [in French].

[39] Mathieux F, Rebitzer G, Ferrendier S, Simon M, Froelich D. Ecodesign in the European electr(on)ics industry - an analysis of the current practices based on cases studies. Journal of Sustainable Product Design 2001;1(4):233-45.

[40] AFNOR. Integrating environmental aspects during the design of products - general principles and application. Paris (France): Association Française de Normalisation; 1998. FD X30-310.

[41] ISO. Environmental management - integrating environmental aspects into product design and development. International Standard Organisation; 2002. ISO 14062.

[42] Pnueli Y, Zussman E. Evaluating the end-of-life value of a product and improving it by redesign. International Journal of Production Research 1997;35(4):921-42.
[43] Tonnelier P, Millet D, Le Coq M, Richet S. Design for recovery: evaluation of the recovery aptitude and integration in design process. Ingénieurs de l'Automobile; September 2002. p. 68-72.

[44] Ensam/Ademe. Integrating the end-of-life aspects during the design of electr(on)ic products. Technical report, Chambéry: Ensam Chambéry Ademe; 2002 [in French].

[45] CEC. Directive of the European Parliament and of the Council on establishing a framework for the setting of Eco-design requirements for Energy-Using Products. Brussels (Belgium); 2003 [2005/32/EC].

[46] CEC. Directive of the European Parliament and of the Council on end-oflife vehicles. Brussels (Belgium); 2000 [2000/53/CE].

[47] CEC. Proposal for a Directive of the European Parliament and of the Council on the type-approval of motor vehicles with regard to their reusability, recyclability and recoverability. Brussels (Belgium); 2004.

[48] Wei J, Realff MJ. Design of bulk recycling system under uncertainty. In: Proceedings of 8th annual global plastics environmental conference (GPEC), 13-14 February 2002. Detroit (USA).

[49] Recycle.net. Recycler's exchange index - plastic recycling section. Available from: <http://www.recycle.net/Plastic/index.html>; 2002 [accessed 10.07.02].

[50] Arola D, Allen L, Biddle M, Fisher M. Plastics recovery from electrical and electronic durable goods: an applied technology and economic case study. In: Proceedings of SPE annual recycling conference. American Plastics Council; 1999.

[51] CODDE. Environmental information and management explorer (EIME) indicators manual. Available from: http://www.codde.fr/english/plaquette/ eime\%20indicator\%20manual_1.7.pdf; 2005 [accessed 19.01.05].

[52] Hunkeler D, Vanakari E. Ecodesign and LCA - survey of current uses of environmental attributes in product and process development. International Journal of LCA 2000;5(3):145-51.

[53] Mathieux F, Froelich D, Moszkowicz P. Recovery conscious design of products: a new method integrating the complexity and the uncertainty of recovery routes. In: Proceedings of tenth international seminar on life cycle engineering - engineering for sustainable development: an obligatory skill of the future engineer, 22-23 May 2003. Copenhagen (Denmark); 2003.

[54] Mathieux F, Froelich D, Moszkowicz P. Toward a better recovery conscious design of products: using recyclability indicators during the design of product. Waste, Sciences and Techniques - Francophone Journal of Industrial Ecology 2003;31:3-13 [in French].

[55] Aboussouan L, Russo P, Pons M, Thomas D, Birat JP, Leclerc D. Steel scrap fragmentation by shredders. Powder Technology 1999;105:288-94.

[56] Zhang S, Forssberg E. Intelligent liberation and classification of electronic scrap. Powder Technology 1999;105:295-301.

[57] Zhang S, Forssberg E, Arvidson B, Moss W. Separation mechanisms and criteria of a rotating eddy-current separator operation. Resources, Conservation and Recycling 1999;25:215-32.

[58] Shen H, Pugh RJ, Forssberg E. Floatability, selectivity and flotation separation of plastics by using a surfactant. Colloids and surfaces - Physicochemical and engineering aspects 2002;196:63-70. 